
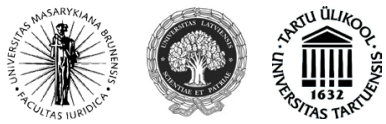

ISSN 2029-2244 (online)

SOCIALINIŲ MOKSLŲ STUDIJOS

SOCIETAL STUDIES

2014, 6(3), p. 706-740.

\title{
RADIKALIAI DEMOKRATINĖS RESPUBLIKOS VIZIJA: STEIGIAMOJO SEIMO SOCIALDEMOKRATŲ FRAKCIJOS NUOSTATOS PRIIMANT 1920 M. LAIKINĄJĄ IR 1922 M. NUOLATINĘ LIETUVOS RESPUBLIKOS KONSTITUCIJAS
}

\author{
Gintaras Mitrulevičius \\ Mykolo Romerio universiteto Politikos ir vadybos fakulteto \\ Politikos mokslų institutas \\ Valakupių g. 5, LT-10101 Vilnius, Lietuva \\ Tel.: (+370) 52740611 \\ El.paštas mitrgint@mruni.eu
}

Pateikta 2013 m. sausio 27 d., parengtas spaudai 2014 m. lapkričio 17 d.

doi:10.13165/SMS-14-6-3-16

Anotacija. Straipsnyje aptariamas Lietuvos Respublikos Steigiamojo Seimo socialdemokratu frakcijos bei apskritai to meto Lietuvos socialdemokratu partijos santykis su Lietuvos Respublikos $1922 \mathrm{~m}$. Konstitucijos priemimo procesu. Ištyrus ir rekonstravus to meto socialdemokratu nuostatas, tiek priimant $1920 \mathrm{~m}$. laikinaja Konstitucija, tiek ir 1922 m. rugpjūčio 1 d. nuolatinę Konstitucija, galima teigti, kad to meto socialdemokratai sieke Lietuvoje įtvirtinti kiek galima radikalesnę parlamentinę demokratinę valdymo forma, kuri turejjo ịtvirtinti ne tik radikalia politinę, bet ir socialinę bei ekonomine demokratiją. Ypač nesutaikomai priešiški to meto Lietuvos socialdemokratai buvo dèl, ju nuomone, demokratijai prieštaraujančios prezidento institucijos. Konstatuotina, kad to meto socialdemokratu konstitucinés nuostatos buvo veikiamos „laikmečio dvasios“, kilusios iš nedemokratiniu monarchiju griūties po 1917-1918 m. revoliucijų bei po Pirmojo pasaulinio karo pasireiškusio „demokratinio entuziazmo“, radikaliai parlamentines "prancūziškos" demokratijos versijos išpopuliarèjimo bei Šveicarijos konstitucinès politi-

Socialinių mokslų studijos / Societal Studies

(C) Mykolo Romerio universitetas, 2014

(C) Mykolas Romeris University, 2014
ISSN 2029-2244 (online)

http://www.mruni.eu/lt/mokslo_darbai/SMS/ http://www.mruni.eu/en/mokslo_darbai/SMS/ 
nés tradicijos itakos. Taip pat to meto Lietuvos socialdemokratu konstitucinems nuostatoms didele įtaka dare vadovavimasis viena iš to meto radikalesnių socialistiniu marksistinés socializmo doktrinos interpretaciju, jų bendrosios ideologinés-politinés nuostatos bei politine laikysena juairiais politinio ir socialinio visuomenès gyvenimo klausimais, socializmo ideologine tradicija apskritai, taip pat to meto europinio socialistinio judejimo raidos ypatybès bei, žinoma, to meto pačios LSDP veiklos aplinkybès ir to istorinio laikotarpio Lietuvos politinès kultūros ypatybès.

Reikšminiai žodžiai: Steigiamasis Seimas (St. Seimas), Lietuvos Respublikos Konstitucija (1922 m.), socialdemokratu frakcija, LSDP.

\section{Ivadas}

2012 m. rugpjūčio 1 d. suejo 90 metų nuo pirmosios nuolatinès tarpukario Lietuvos Respublikos Konstitucijos prièmimo. Kaip savo knygoje „Lietuvos valstybès konstitucijų istorija“ rašè jos autorius teisès istorikas Mindaugas Maksimaitis, „Steigiamojo Seimo priimtos Lietuvos Valstybès Konstitucijos įsigaliojimas“ buvo „nepaprastai reikšmingas atkurtos Lietuvos valstybės gyvenimo ịvykis“1. M. Maksimaičio nuomone, ši Konstitucija „ı tvirtus teisinius rèmus įstatė iki to buvusią laikiną valstybès valdžios sistemą, padejo Lietuvos Respublikos konstitucinius pagrindus, tuo faktiškai užbaigdama nepriklausomos valstybės atkūrimo procesą “2. Tad natūralu, kad ši Konstitucija bei jos priemimo procesas (nors pastarasis mažiau) yra susilaukę dėmesio tiek Lietuvos konstitucionalizmo istorijos bei apskritai teisès istorijos literatūroje $e^{3}$, tiek apskritai istorinèje literatūroje4. Vis dèlto kai kurie šios Konstitu-

1 Maksimaitis, M. Lietuvos valstybés konstituciju istorija. Vilnius: Justitia, 2005, p. 169.

$2 \quad$ Ibid.

$3 \quad$ Ibid., p. 97-157. Taip pat žr. Rèmeris, M. Lietuvos konstitucinès teisès paskaitos. Vilnius: Mintis, 1990, p. 96-103, 122-140; Račkauskas, K. Lietuvos konstitucinés teisés klausimai. New York: s.n., 1967; Maksimaitis M.; Vansevičius, S. Lietuvos valstybès ir teisés istorija. Vilnius: Justitia,1997, p. 138-151; Maksimaitis, M. Lietuvos teises šaltiniai 1918-1940 metais. Vilnius: Justitia, 2001, p. 31-35; Lietuvos Respublikos konstitucinè teisè. Vilnius: Lietuvos teisès universitetas, 2001, p. 140-147; Lietuvos teisés istorija. Vilnius: Justitia, 2002, p. 325-35; Mūsu konstitucionalizmo raida. Vilnius: Seimo 1-kla „Valstbès žinios“, 2003; Maksimaitis, M. Parlamentarizmo teisinis reguliavimas Lietuvoje 1918-1940 metais. Parlamentas ir valstybines valdžios institucijų sąranga. Liber Amicorum Česlovui Juršénui. Vilnius: Mykolo Romerio universitetas, 2008, p. 44, 47-50; Prezidentas valstybinés valdžios institucijų sistemoje. Vilnius: Leidykla MES, 2011, p. $18-25$.

4 Daugirdaitė-Sruogienè, V. Lietuvos Steigiamasis Seimas. New York: Lithuanian National Fuondation Inc Tautos fondas,1975, p. 71-76, 176-194; Noreikienè, S. Buržuazinès partijos seimų rinkimuose buržuazinio parlamentinio režimo Lietuvoje metais (1920-1926). 1. Steigiamojo Seimo rinkimai. Lietuvos TSR Mokslu akademijos darbai, A serija. 1978, 1(62): 89-101; Čepenas, P. Naujujų laikų Lietuvos istorija. T.2. Chicago: Dr. Kazio Griniaus fondas, 1986, p. 683-684, 694-699; Švoba, J. Seimine ir prezidentiné Lietuva. Vilnius: Vyturys, 1990, p. 91-96; Jakštas, J. Nepriklausomos Lietuvos istorija. Chicago, 1992, p. 43-44, 60-62; Truska, 
cijos prièmimo proceso aspektai dar nèra pakankamai ištyrinèti mokslinėje literatūroje. Vienu iš tokių nepakankamai ištyrinètų aspektų galima laikyti atskirų politinių partijų nuostatas šios Konstitucijos prièmimo procese. Šiame straipsnyje ir aptariama vienos iš parlamentinių Steigiamojo Seimo (toliau (jeigu ne citata) - St. Seimo) partijų - Lietuvos socialdemokratų partijos (LSDP) ir jos frakcijos nuostatos ir politiné laikysena 1922 m. nuolatinès Lietuvos Respublikos Konstitucijos priemimo procese. Taigi tai ir būtų šio straipsnio objektas.

Nors socialdemokratų frakcijos nuostatos dèl laikinosios bei nuolatinès Lietuvos Respublikos konstitucijų ir yra susilaukusios šiek tiek istorikų dèmesio ir daugiau ar mažiau glaustai bent jau kai kuriais aspektais apibūdintos ${ }^{5}$, tačiau, žvelgiant plačiau, iki šiol jos mokslinèje literatūroje išsamiai ir sistemiškai nei rekonstruotos, nei pristatytos nebuvo ${ }^{6}$.

Taigi šio straipsnio tikslas yra nuosekliai, sistemiškai ir išsamiai, kiek leidžia straipsnio apimtis, ištirti, rekonstruoti, pristatyti ir aptarti St. Seimo socialdemokratų frakcijos ir LSDP apskritai nuostatas $1920 \mathrm{~m}$. birželio 2 d. laikinosios bei $1922 \mathrm{~m}$. rugpjūčio $1 \mathrm{~d}$. nuolatinès Lietuvos Respublikos konstitucijų prièmimo procese. Tai padès geriau suvokti to meto Lietuvos socialdemokratų politinès ideologijos nuostatas bei pažinti lietuviškosios istorinès socialdemokratijos politinès minties tradiciją. Pagrindiniai šaltiniai, kuriais remtasi rašant straipsni, buvo Lietuvos Respublikos Steigiamojo Seimo stenogramos („Steigiamojo Seimo darbai“ (1920-1922) bei „Socialdemokrato" laikraštis. Rengiant straipsnị taikytas istorinių šaltinių - dokumentų

L. Steigiamasis Seimas ir jo vieta naujųjų laikų Lietuvos istorijoje. Lietuvos Steigiamojo Seimo (1920-1922 metu) narių biogragfinis žodynas. Vilnius: Vilniaus pedagoginio universiteto leidykla, 2006, p. 46-50; Blažytė-Baužienè, D.; Tamošaitis, M.; Truska, L. Lietuvos Seimo istorija XX-XXI a. pradžioje. Vilnius: Baltos lankos, 2009, p. 80-85.

5 Žr. Blažyte, D. Socialdemokratų frakcija Steigiamajame Seime. Socialine demokratija Lietuvoje: LSDP ištakos ir raida. Vilnius: Vilniaus universiteto leidykla, 1996, p. 42-47; Kašauskienè, V. Socialdemokratų opozicija LKDP konstitucinèms nuostatoms Steigiamajame Seime. Lietuvos Respublikos Konstitucija penkeriu metu perspektyvoje. Konferencijos medžiaga. Vilnius: LII leidykla,1998, p. 89-98; Mitrulevičius, G. Socialdemokratai Lietuvos Respublikos seimuose 19201927. Socialdemokratai Lietuvos Respublikos seimuose. Vilnius: Petro ofsetas, 2006, p. 68-71; Mitrulevičius, G. Socialdemokratų (LSDP) santykis su Lietuvos Respublikos demokratizacijos procesu Steigiamojo Seimo darbo metu 1920-1922 m. Parlamento studijos. 2010, 9: 92-102; taip pat žr. Daugirdaitè-Sruogienė, V., supra note 4, p. 178, 180-193; Noreikienė, S., supra note 4, p. 89-101; Vilčinskas, J. Lietuvos socialdemokratija kovoje dél krašto nepriklausomybès. Istorine apžvalga. London: Nida Press, 1985, p. 127-130, 151-155; Mačionis, Z; Čepinskis, J. Profesorius Vincas Čepinskis. Vilnius: Mokslas, 1992, p. 66-74; Jakštas, J., supra note 4, p. 43-44, 60-62; Ilgūnas, G. Steponas Kairys. Vilnius: Vaga, 2002, p. 154, 163-165; Truska, L., supra note 4, p. 46-47; Blažytė-Baužienė D.; Tamošaitis, M.; Truska, L., supra note 4, p. 81-82.

6 Tam tikra išimtis būtų pirminis (ir ne visus akademinei publikacijai būtinus elementus turintis) šio straipsnio variantas publikuotas ne moksliniame leidinyje, o „visuomenès, politikos, kultūros ir istorijos žurnale „Gairès“. Žr. Mitrulevičius, G. Socialdemokratai 1922 metų Lietuvos Respublikos Konstitucijos priemimo procese (1920-1922 m.). Gairés. 2007, 7: 32 - 39; 8: 26-35. 
analizès metodas vadovaujantis hermeneutine tyrinejjimo strategija. Hermeneutinè tyrinejjimo strategija „remiasi didelę reikšmę turinčiais šaltiniais, kuriuose atsispindi buvusios žmogaus veiklos apibrèžtumas ir veikèjų savivoka"7. Kaip rašo istorijos mokslo teoretikas Jörnas Rüsenas, „istorinis tyrinejjimas hermeneutinès strategijos ribose pateikia naujų istorinių žinių iš pačiuose šaltiniuose sudètų elementų „tradicijos“ šviesoje (objektyvuotų prasmès apibrèžtumų prasme) ${ }^{\text {“8 }}$.

\section{Steigiamojo Seimo socialdemokratų frakcija laikinosios Lietuvos Respublikos Konstitucijos prièmimo procese}

Pagrindinis savo valstybingumą atkuriančios (modernų valstybingumą kuriančios) Lietuvos valstybès St. Seimo uždavinys (kaip ir kitų valstybių steigiamųjų parlamentų - konstituantų) buvo priimti pagrindinị valstybès įstatymą - Konstituciją. Iki St. Seimo darbo pradžios veikusi Lietuvos Valstybės Tarybos priimta (1919 0404 ) laikinoji Konstitucija (kaip ir prieš tai labai trumpą laiką veikę 19181102 priimti Lietuvos Valstybès Laikinosios Konstitucijos pamatiniai dèsniai) buvo laikino pobūdžio pagrindinis valstybės ịstatymas, kuris turèjo būti St. Seimo pakeistas nuolat veikiančia Lietuvos valstybès konstitucija. $1918 \mathrm{~m}$. vasario $16 \mathrm{~d}$. Lietuvos valstybès atkūrimo akte buvo sakoma, kad „Lietuvos valstybės santvarką ir jos santykius su kaimynais galutinai turi nustatyti demokratiniais principais išrinktas Lietuvos Steigiamasis Seimas“. Tai buvo pažymėta ir abiejų iki St. Seimo darbo pradžios galiojusių laikinųjų Lietuvos valstybès konstitucijų preambulèse? .

Kaip rašė Lietuvos teisininkas, konstitucinės teisės specialistas Mykolas Romeris, St. Seimas „turèjo tvirtai organizuoti įsteigtą Lietuvos valstybę ir jos valdžios, ir net jos pačios laikinąji pobūdị pakeisti tvirtu nuolatinès valstybès ir valdžios pobūdžiu, taip sakant ją įteisinti ir stabilizuoti"10. Tad jau antrame savo posėdyje St. Seimas nutarè iš Seimo narių sudaryti naują komisiją laikinosios konstitucijos projektui parengti ${ }^{11}$. Mat parengti turejjusią nuolat veikti konstituciją buvo didelis ir ilgas darbas. Pasak M. Romerio, „nuolatinès pastovios konstitucijos suprojektavimas, paruošimas ir prièmimas, sudarąs pamatinị Steigiamojo Seimo funkcijos elementą, buvo reikalingas ilgesnio laiko“12. Tačiau kadangi pats St. Seimo „buvimo faktas (...) griovè iki tol veikusią 19190404 Konstituciją, kuri ir pati buvo numačiusi valstybès valdžios konstrukciją iki Steigiamojo Seimo sušaukimo" "13, tai reikèjo priimti laikinąją konstituciją,

7

$8 \quad$ Ibid.

9 Žr. Lietuvos Valstybès Laikinosios Konstitucijos pamatiniai dèsniai. Lietuvos valstybès konstitucijos. Vilnius: Mokslas, 1989, p. 7-8.

10 Remeris, M., supra note 3, p. 86.

11 Steigiamojo Seimo darbai, 2 p-dis, 192005 17, p. 8.

12 Rèmeris, M., supra note 3, p. 93.

13 Ibid. 
kuri galiotų tol, kol bus parengta nuolatinè Lietuvos valstybės konstitucija. Tuo tikslu ir buvo sudaryta minètoji komisija laikinosios Konstitucijos projektui parengti ${ }^{14}$.

Tiesa, konstitucijos, kurią turètų priimti St. Seimas, rengimo procesas vyko ir iki jo darbo pradžios. Dar 1919 m. gruodžio 5 d. Ministrų kabineto nutarimu buvo sudaryta komisija iš devynių narių „,konstitucijos projektui išdirbti“' ${ }^{15}$. Ši Lietuvos Konstitucijos projekto rengiamoji komisija savo darbą pradejjo $1919 \mathrm{~m}$. gruodžio $15 \mathrm{~d}$. ir baigè jau pradejjus darbą St. Seimui $1920 \mathrm{~m}$. birželio 8 d., iš viso surengusi 28 posèdžius ${ }^{16}$.

Nors ši komisija buvo parengusi tam tikrą konstitucijos projektą, St. Seimas, kaip minejjome, sudarè savo komisiją naujam - iš pradžių tik laikinajam Konstitucijos projektui parengti. Jis buvo pristatytas ir pradètas svarstyti $1920 \mathrm{~m}$. gegužès 21 d. vykusiame 5-ame St. Seimo posedyje ${ }^{17}$. Šio projekto pagrindu $1920 \mathrm{~m}$. birželio 2 d. buvo priimta ir $1920 \mathrm{~m}$. birželio 10 d. ịsigaliojo trečioji laikinoji Lietuvos Respublikos Konstitucija.

Koks buvo Lietuvos socialdemokratų partijos (LSDP) frakcijos santykis su šios Konstitucijos projekto parengimu bei priemimu bei kokios apskritai buvo to meto Lietuvos socialdemokratų konstitucinès nuostatos?

Taigi, nors Konstitucijos projekto rengime dalyvavo LSDP frakcijos atstovas V. Čepinskis, tačiau tiek jo, tiek ir jo atstovaujamos frakcijos nuomonès su St. Seimo daugumos atstovų komisijoje nuomone dèl Konstitucijos turinio išsiskyré, dèl to socialdemokratų frakcija parengè savo atskirą Lietuvos laikinosios konstitucijos projektą. Jị tame pačiame 5-ame St. Seimo posėdyje pristatė V. Čepinskis ${ }^{18}$.

Pagal ši projektą Lietuvos valstybè turèjo būti demokratinė respublika, kurioje St. Seimas yra visos Lietuvos valdžios ir galios reiškejjas ${ }^{19}$. Visi iki šios konstitucijos veikę ịstatymai, kol jie nebus St. Seimo pakeisti, turejo likti galioti. St. Seimas turejo leisti įstatymus ir prižiūrèti jų vykdymą. Vykdyti ịstatymus St. Seimas turẻjo pavesti Seimo pirmininkui ir Ministerių kabinetui. Seimo pirmininkas turejo pirmininkauti Seimui, atstovauti valstybei, skirti iš Seimo narių ministrą pirmininką Ministrų kabinetui sudaryti, skirti valstybès kontrolierių, priimti Ministrų kabineto bei valstybės kontrolieriaus atsistatydinimus.

Ministrais, pagal LSDP pateiktą laikinosios konstitucijos projektą, galèjo būti tik Seimo nariai. Ministrų kabinetas turèjo būti atsakingas tik Seimui ir šiam išreiškus nepasitikèjimą turèjo atsistatydinti. Visi piliečiai turẻjo būti lygūs prieš ịstatymą nepaisant lyties, tautybės, tikejimo. Pasisakyta už luomų, titulų, ordinų ir mirties bausmès panaikinimą, Seimo nario neliečiamumą bei kad visiems Lietuvos gyventojams

Steigiamojo Seimo darbai. 2 p-dis, 192005 17, p. 8.

Žr. Lietuvos konstitucijos projekto rengiamosios komisijos byla. LCVA. F. 923. Ap. 1. B. 122.

L. 77; Maksimaitis, M. Mažoji Konstituanta. Lietuvos Taryba atkuriant valstybingumą. Vilnius: Justitia, 2011, p. 342-346.

Ibid.

Steigiamojo Seimo darbai, 5 p-dis,1920 05 21, p. 27.

Ibid.

Ibid. 
būtų suteikta asmens, buto ir korespondencijos „neliečiamybë“, taip pat „žodžio, spaudos, darbo, gyvenimo, tikybos, ịsitikinimų, draugijų, susirinkimų ir streikų laisvë“. Taip galima būtų apibūdinti LSDP frakcijos parengtą laikinosios konstitucijos projektą, kurị frakcijos vardu pristatęs V. Čepinskis prašė Seimą priimti jị kaip Valstybès Konstitucijos pagrindą ${ }^{20}$.

Galima teigti, kad LSDP frakcija griežtai pasisakè už radikaliai parlamentinę respubliką, kurioje visa „suvereni Lietuvos valdžia priklauso liaudžiai“, kur Seimas yra minètos liaudies suverenios „valdžios ir galios reiškejjas“ bei svarbiausia ir pagrindinè valdžios institucija ir kur „Prezidento institucijos iš viso nebūtų, o kraštui reikale atstovautų Seimo pirmininkas“21.

Palyginę socialdemokratų ir Seimo komisijos parengtus laikinosios Konstitucijos projektus, matyt, galime sutikti su istoriografijoje jau išsakyta nuomone, jog tarp jų buvo ryškūs skirtumai ${ }^{22}$. Tai St. Seimo posėdyje pažymejjo ir pagrindinis socialdemokratų frakcijos kalbètojas konstitucijos klausimais V. Čepinskis. Jis teigè, kad tarp jo frakcijos ir St. Seimo sudarytos komisijos parengtų laikinosios Konstitucijos projektų yra, nors ir „liečiantis gal ne daugeli punktų“, tačiau vis dèlto „labai didelis skirtumas“23. 1920 m. gegužès $27 \mathrm{~d}$. išẻjusiame „Socialdemokrato“ numeryje kaip tie „pamatiniai“ skirtumai buvo nurodyti požiūris ị prezidento institucijos reikalingumą bei skirtingi požiūriai į mirties bausmę, luomus bei ordinus ${ }^{24}$.

Apie socialdemokratų dalyvavimą rengiant 1920 m. laikinąją Konstituciją šiek tiek rašę istorikai taip pat nurodo šiuos tris minètų projektų skirtumus ir dar du - požiūrị i ̣inistrų kabineto formavimą ir kariuomenės vado skyrimą ${ }^{25}$. Galima pritarti istorikès D. Blažytès nuomonei, kad Seimo komisijos ir LSDP frakcijos projektuose nesutapo keturios pagrindinès nuostatos: 1) dèl prezidento institucijos; 2) dèl ministrų kabineto sudarymo; 3) dèl karo vado skyrimo ir 4) dèl mirties bausmès panaiki$\operatorname{nimo}^{26}$.

Pirmas „pamatinis“ skirtumas tarp socialdemokratų rengto Konstitucijos projekto ir St. Seimo komisijos rengto laikinosios Konstitucijos projekto buvo požiūris i prezidento instituciją. Socialdemokratai pasisakẻ prieš prezidento instituciją. Paminètina, kad dar iki St. Seimo darbo pradžios dirbusioje Lietuvos Konstitucijos projekto rengimo komisijoje dalyvavęs socialdemokratas teisininkas A. Janulaitis griežtai pasisakè prieš prezidento institucijos įvedimą būsimojoje Lietuvos Konstitucijoje ${ }^{27}$.

Supra note 17.

21 Ibid., p. 28; 9 p-dis, 192005 31, p. 72.

22 Žr. Blažytè, D., supra note 5, p. 44; Kašauskienè, V., supra note 5, p. 90.

23 Steigiamojo Seimo darbai. 5 p-dis, 192005 21, p. 28.

24 Prezidento klausimas. Socialdemokratas. 192005 27, Nr. 7 (21), p. 1.

25 Blažytè, D., supra note 5, p. 44; Kašauskienè, V., supra note 5, p. 90.

26 Blažyte, D., supra note 5, p. 44.

27 Žr. Lietuvos konstitucijos projekto rengiamosios komisijos byla. LCVA. F. 923. Ap. 1. B. 122.1.73. 
Socialdemokratų išsakytą St. Seime argumentaciją prieš prezidento institucijos reikalingumą reikètų pradėti pristatyti nuo argumentų, kuriuos savo kalboje pateikè socialdemokratų atstovas laikinosios Konstitucijos projekto rengimo komisijoje V. Čepinskis. Jis, kaip ir visa socialdemokratų frakcija, siūlè neịvesti prezidento institucijos, „nes ji valstybei per brangiai atsieinanti - alga apie 180000 auksinų ir reprezentacija apie 150000 auksinų “28. Šias lèšas, pasak socialdemokrato, galima panaudoti „skurdui krašte sumažinti“. Socialdemokratų požiūriu, prezidento funkcijas gali „atlikti Seimo pirmininkas, kaip Šveicarijoje, Latvijoje, Estijoje“.

Ypač buvo siūloma atkreipti demesị ị Šveicarijos respubliką, kuri, anot V. Čepinskio, „700 metų gyvena be prezidento“ ir dèl to, kad jo ten nèra, yra „labai puiku“. Kaip buvęs Lietuvos atstovas Anglijoje, V. Čepinskis atkreipé dèmesị ir ị Anglijos Karalystę, kur „visa valdžia ir reprezentacija priklauso ne taip vadinamai valstybès galvai, bet ministerių kabinetui“. Anglija, pasak LSDP frakcijos atstovo, „laiko savo tradicijas, bet ji iš jų pašalina viską, kas gali trukdyti visuomenès plètotę “29. Baigdamas dèstyti motyvus prieš prezidento instituciją V. Čepinskis, matyt, remdamasis socialdemokratų požiūriu ị Lietuvos prezidentinę patirtị 1919 m. - 1920 m. pradžioje, pažymejo, kad Lietuvoje „prezidentas labai greit prisiima monarcho ịpročius“ ${ }^{\text {“30. }}$.

Socialdemokratų požiūriu, neigiamos prezidento institucijos Lietuvoje patirties argumentą savo ilgoje kalboje St. Seimo posèdyje (1920 05 26) antrą kartą svarstant laikinosios Konstitucijos projektą pateikė ir socialdemokratų frakcijos St. Seime bei apskritai LSDP politinis lyderis ir ideologas S. Kairys ${ }^{31}$. Jis atkreipe dèmesị ị $1919 \mathrm{~m}$. situaciją, kai, jo manymu, prezidento institucija Lietuvoje suvaidino neigiamą vaidmenị. S. Kairio nuomone, tuo metu dèl prezidento vaidmens liko nenubausti „tie, kurie vykdè terorą ir represijas prieš darbininkų judejimą Lietuvoje ir kurie yra atsakingi už Valiukų ir Smolskio nužudymą “32. S. Kairys taip pat pažymėjo, kad lenkų sukilimo metu kariuomenès vadas S. Žukauskas „vilkino“, nepaisant to, kad Ministrų kabinetas norejjo ji priversti veikti, o prezidentas kariuomenès vadu visiškai pasitikejjo ${ }^{33}$.

S. Kairys tvirtino, kad „prezidentūros sudarymas yra sudarymas antros valdžios, palankios tam tikrom grupem, kurios ją palaiko ir per ją vykdo savo tikslus"34. Tai,

31 Steigiamojo Seimo darbai. 7 p-dis, 192005 26, p. 54-55.

32 Socialdemokratai J. Smolskis ir F. Valiukas bei jo žmona O. Valiukienè buvo nužudyti 1919 m. vasarą savivaliaujančių karininkų. Žr. Bielinis, K. Gana to jungo. New York: K. Bielinio ir Amerikos liet. Socialdemokratų s-gos lit. fondas, 1971, p. 382-387.

33 Turimas mintyje Lenkų karinès organizacijos (POW) $1919 \mathrm{~m}$. vasarą rengtas sukilimas Lietuvoje.

Steigiamojo Seimo darbai. 5 p-dis, 192005 21, p. 29.

kinkos dreba mąstant apie tai, kad darbo žmonès nori paimti ị savo rankas valdžią“, tuo tarpu „Anglijos monarchijoje“, anot buvusio Lietuvos atstovo $1919 \mathrm{~m}$. šioje valstybeje, „tokios galimybès niekas nebijo“.

Ibid.

Pasak S. Kairio, „Amerikos kapitalistai aukoja dešimtis milijonų, kad išrinktų tinkamą žmogų“ 
S. Kairio nuomone, iliustruoja ir "Tarybos praktika“" (turima mintyje Lietuvos Valstybès Taryba - G. M.), kuri „rodo, kad reakcinių ir pasiturinčių grupių buvo ir pas mus méginta vesti gyvenimą slaptos diplomatijos pasigaunant“. Pasak LSDP lyderio, „tiems, kurie nori be Seimo dar rast vietą gint savo reikalus, suprantamas prezidento reikalingumas, bet tie, kurie pasižadejo ginti darbo žmonių reikalus ir nori kad visa teisė pasiliktų Seimo rankose, tiems žmonėms balsuoti už prezidentą reikštų darbo žmonių reikalų pardavimą ar bent pylimą vandens ị malūną tų, kurie bijo išeiti viešumon“. Turèti prezidentą kaip koki „gramofoną“, kuris, S. Kairio nuomone, „tik atgarsintų norus ir reikalus tam tikros visuomenès grupès, yra neleistinas dalykas" ${ }^{\text {"35. }}$.

Griežtai kritikuodamas prezidento institucijos reikalingumą S. Kairys St. Seimo komisijos siūlomo projekto 5 punktą, kuriame buvo sakoma kad „vykdomoji valdžia pavedama Respublikos Prezidentui ir Ministerių kabinetui“, siūlè pakeisti formuluote, kurioje nurodoma kad „vykdomoji valdžia pavedama Ministerių kabinetui ir Seimo pirmininkui“36. S. Kairys kalbejo, jog „jei norima sudemokratinimo pasiekti patị dugną, tai visa galia privalo priklausyti Seimui“ ir kad „Seimas gaudamas mandatą iš žmonių negali perleisti jo tiems, kas neturi teisès juo naudotis“. Kadangi, socialdemokrato nuomone, „pats Seimas gali valdžios visumą reikšti“, todèl „ir visas funkcijas, kurios skiriamos prezidentui, yra arba nereikalingos, arba neleistinos“.

Kaip nereikalingą prezidento funkciją S. Kairys nurode „prezidento atstovavimą kraštui“. Anot LSDP lyderio, tik tokios didelès ir turtingos šalys, kaip Amerika arba Vokietija, gal ir gali leisti turèti prezidentą, bet „tokiai kukliai, mažutei Lietuvos Respublikai kam reikalingas žmogus tas pareigas atlikti?“. Tas pareigas, S. Kairio, kaip ir apskritai socialdemokratų frakcijos, nuomone, gali atlikti ir Seimo pirmininkas. S. Kairio nuomone, ir visos „kitos prievolès ir teisès numatomos projekte“ (St. Seimo komisijos parengtame - G. M.) pavesti prezidentui yra „nesuprantamos, jei Seimas yra vienintelis krašto šeimininkas“. Pasak S. Kairio, yra „nesuprantama“ ir tai, „kaip atsakomas prieš Seimą ir šalị Ministerių kabinetas gali priklausyt nuo prezidento“.

Anot S. Kairio, „išeina, kad valstybès šeimininkas (Seimas - G. M.) negali kviestis ir statyt žmones valstybės darbui vest ir vykint“, nes „tai daro visai kitas žmogus“. S. Kairio nuomone, „nustatomos prezidentui teisès, privilegijos ir prievolès yra nesuprantamos mums (socialdemokratams - G. M.), kaip nuosaikiems (nuosekliems G. M.) demokratams, bet suprantamos tiems, kurie remia prezidentą siekdami savo tikslų".

Kaip ir V. Čepinskis, S. Kairys savo kalboje pažymejjo tai, kad prezidentūra Lietuvai brangiai kainuoja. Anot S. Kairio, ji kainavo „ne 400 tūkst., bet 1,5 milijono auksinų“.

Diskusijose dèl prezidento institucijos reikalingumo Lietuvai dalyvavo ir LSDP frakcijos St. Seime pirmininkas K. Venclauskis, kuris savo pasisakyme pareiškè, kad

ir ,jei tam tikra partija praveda savo kandidatą, ji nepalieka nuskriausta“. Steigiamojo Seimo darbai. 7 p-dis, 192005 26, p. 54-55. 
tokios konstitucijos, kokios projektas čia pateikiamas, „nematė né viena valstybe“, nes čia „nekalbama nei apie teritoriją, nei apie pilietybę, nei apie santykius, kurie kiekvienoj konstitucijoje nurodomi“, bet užtat kalbama apie prezidentą. K. Venclauskio nuomone, „ateityje Seimas pamatys, ar reikalinga prezidento institucija, ar ne, ir tada galès spręsti“".

Prieš prezidento instituciją St. Seimo posèdžiuose pasisakè ir pagal „Darbo žmonių" sąrašus išrinktas, tačiau prie socialdemokratų frakcijos prisijungęs, taigi jos nariu tapęs socialistas liaudininkas K. Lekeckas. Pasak jo, „norima įsteigti dar vieną instituciją (...), kuri sulaikytų darbo mases, jeigu jos norètų iš pavergejų išsiveržti ${ }^{\text {“37. }}$ Teigdamas, kad prezidentas Lietuvai nereikalingas, K. Lekeckas atkreipe demesị ị tai, kad „Estai ir Latviai tomis pačiomis aplinkybemis ruoše konstituciją, o apsèjo be prezidento".

K. Lekeckas tvirtino, kad svarstant prezidento klausimą susidūrẻ dvi - „sena ir nauja pasaulěžiūros“. Prezidento, sakè K. Lekeckas, „nori tie, kurie negali atsiskirti nuo senų katalikybės tradicijų“, kurie "nenori atiduot valdžios žmonėm Lietuvoje“

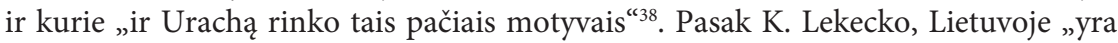
apie 20 buržujukų, kurie nori valdyt per išrinktą iš savo tarpo prezidentą (...). Jie visur rèkia, kad mužikai nori karaliaus, jie ir dabar nori Uracho, tik kitokiu vardu“"39. K. Lekeckas teigè, kad „darbo žmonés nenori prezidento, kad 90 procentų Lietuvos žmonių yra prieš prezidentą".

Prieš prezidento institucijos įvedimą Lietuvoje buvo griežtai pasisakyta nepasirašytame, tačiau greičiausiai S. Kairio parašytame $1920 \mathrm{~m}$. gegužès 27 d. „Socialdemokrato“ numerio vedamajame straipsnyje „Prezidento klausimas" ${ }^{\text {"40 }}$. Čia buvo pabrěžta, kad „socialdemokratai stovi už tai, kad Lietuvos Respublikoj nebūtų renkamas Prezidentas, kad visa valia ir galè būtų išimtinai Seimo rankose, o kraštui atstovautų reikale Seimo pirmininkas“. Taip pat čia buvo pažymèta, kad „pasipraktikavę Tarybos laikais su p. Smetona“, Seimo dauguma („krikščionys“) „nori prezidento“, nes jie „gavo ịsitikinti, kad ir prezidentą galima išnaudoti saviems reikalams“.

Straipsnio „Prezidento klausimas“ autoriaus nuomone, kada „krikščionys“ kartu su „Pažangos“ žmonèmis „vedè pas mus reakcinị režimą, steigẻ komendantūras, rèdè karo stovị, taisè sąlygas komendantams ir milicijai sauvaliauti, jie visuomet mokedavo susipažinti su p. prezidentu ir savaip padaryti“. Pasak cituojamo straipsnio, „taip buvo net Sleževičiaus Kabineto laikais“, kada prezidentas „buvo reikalingas ir naudingas“, kai „tekdavo gelbèti tokie didvyriai, kaip Glovackis, nuo teismo ir kalè-

Steigiamojo Seimo darbai. 9 p-dis, 192005 31, p. 66.

Turima mintyje Lietuvos Tarybos $1918 \mathrm{~m}$. liepą priimti nutarimai Lietuvą paskelbti monarchija bei Lietuvos karaliumi išrinkti Vilhelmą fon Urachą. Socialdemokratai šiuos nutarimus aštriai kritikavo. Šie nutarimai buvo panaikinti $1918 \mathrm{~m}$. lapkričio pradžioje. Žr. Mitrulevičius, G. Socialdemokratų santykis su Lietuvos (Valstybès) Taryba 1918 m.: nuo Vasario 16-osios Akto priemimo iki Pirmojo pasaulinio karo pabaigos. Parlamento studijos. 2013, 14: 91-135.

Steigiamojo Seimo darbai. 9 p-dis, 192005 31, p. 66.

Prezidento klausimas. Socialdemokratas, supra note 24, p. 1. 
jimo“ ir kai reikedavo "pridengti ar sustabdyti tokias klaikias bylas, kaip Valiukų ir Smolskio užmušimas“.

"Socialdemokrato" vedamojo autoriaus nuomone, Lietuvos Tarybos darbo laikais prezidentas padėdavo krikščionims demokratams „vesti savo politiką (...) pastatyti priešaky sau tinkamus žmones ir su jų pagalba vesti sau tinkamas darbas ir namie, ir užsieniuose“. Straipsnio autoriaus teigimu, „geriausiai“ krikščionims demokratams „buvo tas, kad vedant savo politiką buvo galima lig soties kuždentis prezidento kabinete, pasislépus nuo „svieto“ akių, viską slaptai paruošti, sudaryti ir tik po to viešumon iškelti kaipo ịvykusị atsitikimą, iškelti ne savo, bet to paties prezidento vardu“. Cituojamo straipsnio autorius tuo nesistebi, nes, kad „klerikalai ir jų sèbrai mègsta politikoj patamsį, slaptąją diplomatiją ir vengia rodyti minioms tikrąji savo veidą, tai suprantama, - dvasininkija jau šimtai metų, kaip tais keliais eina“.

Apžvelgiamo straipsnio autorių stebino ne krikščionių demokratų pozicija, o pozicija už prezidento instituciją pasisakiusiụjų dalies liaudininkų, kurie „,negali nežinoti, kad prezidentas paims iš krašto atstovybès dalị jos teisių ir tuo pasinaudodamas pasistengs sudaryti šalimai Seimo dar kitą valdžią“. Pasak autoriaus, „liaudininkai dar iš p. Sleževičiaus praktikos turètų žinoti, kaip liaudies siekimų priešai yra uolūs išnaudoti saviems reikalams tą valdžios dvejopumą, slèpdamies už prezidento nugaros“. Straipsnio autorius prašè „meldžiamuosius socialistus liaudininkus demokratus paaiškinti, kuo vadovaudamiesi jie prisikinkè prie „krikščionių“ vežimo, padėdami sukti jo ratus reakcijos balon (...).

Svarstant laikinosios Konstitucijos projektą prezidento institucijos klausimu St. Seime pasisakè visų partijų atstovai ir jų nuomonės skyrėsi. Nesutapo ir dviejų ryškiausių valstiečių liaudininkų bloko politikų K. Griniaus ir M. Seževičiaus nuomonès. K. Grinius laikėsi nuomonès, kad tai, kas buvo kalbèta prieš prezidento instituciją, iš tikrųjų buvo pasakyta ne prieš prezidento instituciją apskritai, bet konkrečiai prieš A. Smetoną. Tuo tarpu M. Sleževičius pasisake prieš prezidento instituciją apskritai. Jo manymu, šios funkcijos galinčios būti pavestos iš dalies ministrui pirmininkui, iš dalies Seimo prezidiumui41. Diskusijoje dalyvavę krikščionių demokratų bloko atstovai pasisakè už prezidento instituciją. Štai LKDP atstovas kun. J. Staugaitis teigé, kad „nenorint prezidento reikia daryti eksperimentą, o darant eksperimentą dažnai daroma valstybei žalos". Kitas krikščionis demokratas J. Purickis patare elgtis atsargiai, nes valdžios funkcijų jungimas galįs pakenkti valstybei, kuri dar užsienio nepripažinta, kad Lietuva gali būti ịtarta einanti prie bolševizmo ${ }^{42}$.

Būti ar nebūti prezidento institucijai laikinoje Lietuvos Konstitucijoje buvo sprendžiama gegužès $31 \mathrm{~d}$. balsuojant atviru balsavimu. „Už“ balsavo 54 krikščionių demokratų bloko atstovai ir 2 žydų frakcijos nariai, susilaikè 5 liaudininkai ir

41 Daugirdaitė-Sruogienè, V., supra note 4, p. 73. Apie valstiečių liaudininkų bloko poziciją šiuo klausimu plačiau žr. Maksimaitis, M. Lietuvos valstybès konstitucijų istorija, supra note 1 p. 99. 
1 lenkų frakcijos narys. „Prieš“ balsavo 12 socialdemokratų, 20 valstiečių liaudininkų bloko atstovų, 1 vokietis, 1 lenkas ir 2 krikščionių demokratų bloko atstovai ${ }^{43}$. Taigi prezidento institucija buvo ịtvirtinta laikinojoje Lietuvos Respublikos Konstitucijoje.

Tiesa, oficialiai prezidentas St. Seime išrinktas nebuvo. 1920-1922 m. iki tol, kol susirinko ị savo posèdžius Pirmasis Lietuvos Respublikos Seimas, A. Stulginskis, kaip St. Seimo pirmininkas, buvo oficialiai tituluojamas kaip „einantis Respublikos prezidento pareigas Steigiamojo Seimo pirmininkas" ${ }^{44}$. M. Maksimaičio nuomone, "griežtas Steigiamojo Seimo kairès pasisakymas prieš prezidento institutą ir likusius skatino ieškoti kompromiso" ir kad tai buvo būdinga ir 1920 m. birželio 19 d. koalicinę vyriausybę su valstiečiais liaudininkais sudariusiems krikščionims demokratams, ir dèl to galiojant St. Seimo priimtajai laikinajai Konstitucijai prezidentas nebuvo renkamas ${ }^{45}$.

Diskusija dèl prezidento institucijos reikalingumo Lietuvoje bei šios institucijos kompetencijų nesibaigè. Ji vyko ir nuolatinès Lietuvos Respublikos Konstitucijos rengimo ir prièmimo proceso metu 1921-1922 m. Socialdemokratų poziciją ir argumentus šios diskusijos metu aptarsime velliau, kai bus pristatomos LSDP frakcijos nuostatos nuolatinès Konstitucijos projekto rengimo, svarstymo ir priemimo procese. Dabar gi grižkime prie St. Seimo socialdemokratų nuostatų $1920 \mathrm{~m}$. birželio 2 d. laikinosios Konstitucijos priėmimo procese ir apžvelkime likusius socialdemokratų rengto Konstitucijos projekto ir St. Seimo komisijos rengto laikinosios Konstitucijos projekto skirtumus.

Be pasisakymo prieš prezidento institucijos reikalingumą Lietuvai, antras, anot istorikų, abiejų St. Seimui pateiktų svarstyti laikinosios Konstitucijos projektų skirtumas yra socialdemokratų nuostata, kad Ministrų kabinetas turi būti sudarytas tik iš Seimo narių. Matyt, tai lèmé socialdemokratų siūloma nuostata, kad „St. Seimas yra visos Lietuvos valdžios ir galios reiškejjas“. Tokị savo nusistatymą socialdemokratai grindè ir parlamentinių valstybių politine praktika. Savo kalboje V. Čepinskis tvirtino, kad „visose valstybėse, kur yra parlamentai, ministeriai renkami iš parlamento narių", nors ir „ne visose konstitucijose tai yra fiksuota" ${ }^{\text {"46 }}$.

Kalbèdamas apie kitus minètų dviejų parengtų laikinosios Konstitucijos projektų skirtumus, V. Čepinskis akcentavo socialdemokratų nuostatą, kad karo vadas turi būti geras savo srities specialistas ir kad jis turi būti skiriamas ne prezidento, bet ministro pirmininko ir per pastarąji atsakingas Seimui ${ }^{47}$. Matyt, galima tvirtinti, jog šią nuostatą lẻmé principinis nusistatymas prieš prezidento instituciją, išplaukęs iš Lietuvos politinio gyvenimo $1919 \mathrm{~m}$. patirties, kas, beje (kaip mateme), ne kartą buvo minima socialdemokratų frakcijos narių pasisakymuose prieš prezidento instituciją.

44 Maksimaitis, M. Lietuvos valstybès konstituciju istorija, supra note 1, p. 103.

45 Ibid.

46 Steigiamojo Seimo darbai. 5 p-dis, 192005 21, p. 29.

Ibid. 
Vienu iš svarbiausių punktų socialdemokratai laikė mirties bausmès panaikinimą, kurio St. Seimo komisijos projekte numatyta nebuvo. „Socialdemokrate“ buvo rašoma, kad „Seimo dauguma šiuo klausimu tyli“ todèl, kad ji „nori ją (mirties bausmę - G. M.) palikti“48. „Socialdemokrate“ buvo tarsi ir stebimasi, kad net „Kristaus mokslo mokytojai palaiko mirties bausmę“. Nors čia pat cituojamame straipsnyje buvo pastebima, kad „tas keista, bet ne nauja - juk tie, kurie šiandien krikščionių vardą nešioja ir jų priešaky stovi, darè baisesnių dalykų“. „Socialdemokrate“ buvo teigiama, jog „iškilus (...) karui, krikščioniškoji pravoslaviškoji dvasininkija Kristaus vardu laimino caro armijos ginklą ir su kryžium lydejo juos žmonių žudyti“ bei kad „tą patị darè Vokiečiuose „krikščioniškieji protestantai“, o „Austruose - „krikščioniškieji katalikai“".

Anot čia cituojamo straipsnio autoriaus, „kur tik bažnyčia yra susirišusi su valstybe, kitaip sakant dvasiškija su valdžia, kunigai už gaunamas savo luomui privilegijas teikia tai valdžiai visokios pagalbos, kad ir aukštyn kojomis versdami Kristaus mokslą“. Argi, klausiama straipsnyje, to neparodè ir Lietuvos kunigai „rinkimų metu, kad dèl jų bažnyčia tai tik salè politinei agitacijai varyti“, „Kristaus vardas tai tik geras plakatas savo partijai pareklamuoti, o tikybiniai žmonių jausmai, tai tik opi liaudies vieta, kurion davus dar galima tikinčias aveles gardan suvaryti. “49

St. Seime LSDP frakcijos atstovai aktyviai dalyvavo svarstant mirties bausmès panaikinimo klausimą. Štai V. Čepinskis tvirtino, kad „mirties bausmè niekuomet nepasieks savo tikslo ir visiškai neatsako šios dienos žmonijos sąžinei ir sąmonei“"50. Šio socialdemokrato nuomone, „mirties bausmès padèty glūdi keršto instinktas, vienas iš galingiausių antisocialinių instinktų ir veiksnių“. V. Čepinskis kalbejo: „Mirties bausmès panaikinimo priešai sako, kas daryti su piktadariais panaikinus mirties bausmę? Betgi kada žmogaus gyvybès vertẻ krinta, tada kaip tik auga žmogžudžių skaičius. Reikia pašalinti tikras priežastis (...) nelygybę ir išnaudojimą ir kitus bjaurius kapitalizmo reiškinius (...). Sakoma, kad panaikinus mirties bausmę negalima būsią palaikyti kariuomenèje drausmès. Tai netiesa. Kalbama, kad mes socialdemokratai esame materialistai, bedieviai (...). Doros motyvai mums gal svarbesni už proto nurodymus (...). Visos didžios religijos, kaip ir proto mokslas, draudžia mirties bausmę. "51

Prieš mirties bausmę St. Seimo posėdyje pasisakè ir K. Venclauskis. Priekaištaudamas krikščionims demokratams už žiaurios mirties bausmès palaikymą, jis kalbejjo: „Norèdami atsibrèžti nuo senos valdžios veikimo turime pravesti demarkacijos liniją. Mirties bausme būdavo baudžiami tik politiniai (...) gresiant bolševikų pavojui, taip vadinamus bolševikus taip pat šaudè, bet ką valdžia vadindavo bolševikais, tai buvo visi tie, kurie nesutikdavo su valdžios nusistatymu (...) daug buvo nekaltai sušaudytų

49 Ibid.

$50 \quad$ Steigiamojo Seimo darbai. 5 p-dis, 192005 21, p. 29-30.

51 Ibid. 
žmonių. Visi laikai mums aiškiai rodo, kad tik pradèti mirties bausmę vartoti sunku, o paskui eina ị kasdieninius reiškinius. “" ${ }^{2}$

St. Seime svarstant laikinosios Konstitucijos projektą iš pat pradžiu prieš mirties bausmę pasisake ne tik socialdemokratai, bet ir socialistai liaudininkai demokratai, valstiečių sąjungos atstovai, žydų frakcija. Vèliau, baigiantis diskusijoms dèl laikinosios Konstitucijos projekto, tokiai nuostatai pritare ir krikščionys demokratai. Lietuvos Laikinojoje Konstitucijoje buvo užfiksuota, kad „mirties bausmè naikinama“" ${ }^{\text {" }}$.

Apžvelgiant socialdemokratų nuostatas dèl laikinosios Konstitucijos projekto, reikètų atkreipti dèmesị ị tai, kad jie griežtai pasisake prieš laipsnių ir ordinų įvedimą. Diskutuojant apie atitinkamą laikinosios Konstitucijos projekto punktą V. Čepinskis siūle komisijos formuluotę „Luomų ir titulų nèra“ pakeisti „Luomai, titulai, rangai ir ordinai panaikinami ${ }^{{ }^{5} 4}$. Šis socialdemokratų reikalavimas taip pat nesulauke kitu partijų atstovų pritarimo ir nebuvo ịtrauktas ị Laikinąją Konstituciją.

Taigi socialdemokratams nedaug pavyko pakeisti tas Lietuvos Laikinosios Konstitucijos projekte užfiksuotas nuostatas, kurioms jie nepritarè. Tad suprantama, kad LSDP frakcija, St. Seimui 1920 m birželio 2 d. balsuojant už laikinosios Konstitucijos projekto prièmimą, balsavo prieš daugumos pasiūlytąji projektą, taigi prieš laikinosios Lietuvos Respublikos Konstitucijos prièmimą. Nepaisant, kad prieš balsavo ir dalis valstiečių liaudininkų bloko atstovų, ši laikinoji Konstitucija, kaip jau minèta, $1920 \mathrm{~m}$. birželio $2 \mathrm{~d}$. buvo priimta ir įsigaliojo nuo $1920 \mathrm{~m}$. birželio $10 \mathrm{~d}$.

\section{Socialdemokratų frakcijos nuostatos nuolatinès Lietuvos Respublikos Konstitucijos projekto svarstymo procese $1922 \mathrm{~m}$. (I): tolesnè kova prieš prezidento instituciją}

Nors nuolatinès Konstitucijos projekto rengimo komisijoje buvo dirbama ir 1920 m. ir 1921 m., tačiau St. Seimo plenariniuose posèdžiuose jis buvo pradètas svarstyti tik $1922 \mathrm{~m}$. vasario ménesi, po to, kai buvo priimtas kitas Lietuvos gyvenimui itin svarbus teisès aktas - žemès reformos ịstatymas. Todèl reikia pažymèti, kad, socialdemokratų požiūriu, Konstitucija buvo rengiama per ilgai. Iš to meto Lietuvos socialdemokratų ideologijos išplaukęs ir ja paremtas nuolatinès Konstitucijos rengimo darbo vertinimas buvo pateiktas $1921 \mathrm{~m}$. vasario $10 \mathrm{~d}$. „Socialdemokrate“. Vedamajame straipsnyje buvo rašoma, jog ,iš viso darbo per beveik devynis ménesius vos trečdalis paruošta “ ${ }^{\text {"55 }}$, be to, ir tas konstitucijos rengimo darbas ,juo tolyn ... tuo lètyn eina“. Ir tame „nevykusiame darbe“, pasak cituojamo straipsnio autoriaus, „klerikalai, liaudininkų padedami, vis aiškiau ima žvairuoti dešinèn, turtingųjų pusèn“. Dèl to ir ,jau pradeda rimti išsigandusių dvarininkų širdis ir jų ūpas taisosi“.

53 Steigiamojo Seimo darbai. 10 p-dis, 192006 02, p. 72-74.

54 Steigiamojo Seimo darbai. 9 p-dis, 192005 31, p. 68, 70.

55 Seimo darbus sekant. Socialdemokratas. 192102 10, Nr. 6 (55), p. 1. 
Dirbdami Nuolatinès Konstitucijos rengimo komisijoje LSDP frakcijos atstovai V. Čepinskis ir K. Venclauskis toliau tvirtai gynè LSDP frakcijos nuostatą, kad Lietuvai prezidento institucijos nereikia. Tokią poziciją socialdemokratai gynė ne tik minètos komisijos posėďiuose, ją stengèsi viešai pristatyti ir skleisti bei populiarinti visuomenejje. Kaip to pavyzdi galima paminèti $1921 \mathrm{~m}$. kovo 3, 10, 24 ir 31 dienų „Socialdemokrato" numeriuose Anzelmo pseudonimu pasirašytą V. Čepinskio straipsnị „Ar mums reikia prezidento?", kuriame buvo plačiai dèstomi tie socialdemokratų argumentai prieš prezidento instituciją, kuriuos jie naudojo tiek prieš tai laikinosios Konstitucijos, tiek nuolatinès Konstitucijos priemimo procese ${ }^{56}$.

Nuolatinès Konstitucijos projektui parengti prireikè gana nemažai laiko. Per pusantrų metų ìvyko 90 St. Seimo Konstitucijos komisijos posėdžių. Pirmą kartą šios komisijos parengtas Konstitucijos projektas svarstytas tik $1922 \mathrm{~m}$. vasario $24 \mathrm{~d}$. St. Seimo 176-ame posėdyje. Šiame trumpai trukusiame nuolatinès Konstitucijos projekto pirmajame svarstyme LSDP frakcijos vardu kalbejjo ir labai ilgą kalbą pasakè V. Čepinskis ${ }^{57}$. Antrąji kartą nuolatinès Lietuvos Respublikos Konstitucijos projektas St. Seime buvo svarstomas nuo $1922 \mathrm{~m}$. kovo $8 \mathrm{~d}$. iki gegužès $2 \mathrm{~d}$. devyniuose St. Seimo posėdžiuose. LSDP frakcijos nariai šiame svarstyme dalyvavo itin aktyviai. Antrajame Konstitucijos projekto svarstyme jie išsakè kritines pastabas dèl nuolatinès Konstitucijos projekto bei siūlè savo pataisas net 50 kartų: V. Čepinskis - 21 kartą, K. Bielinis - 10 kartų, K. Venclauskis - 9 kartus, J. Plečkaitis - 7, V. Požela - 2, A. Povylius - 1 kartą $^{58}$.

Dauguma socialdemokratų frakcijos pasiūlymų ir kritinių pastabų buvo atmesta. Tačiau kaip taikliai pastebejo apie socialdemokratų dalyvavimą 1922 m. Konstitucijos prièmimo procese rašiusi istorikè V. Kašauskienè, „socialdemokratai savo konstitucinių nuostatų neišsižadejo“ ir svarstant Konstitucijos projektą trečią kartą (1922 m. liepos pradžia - rugpjūčio 1 d.) jie vèl aktyviai oponavo krikščionių demokratų koalicinès daugumos teikiamam Konstitucijos projektui ir trylikoje posėdžių net 71 kartą išreiškè savo nuomonę, siūlè pataisas, oponavo kitų pasiūlymams ${ }^{59}$. Trečiajame nuolatinès Konstitucijos projekto svarstyme K. Bielinis kalbejo 24 kartus, V. Čepinskis - 17, K. Venclauskis - 14, V. Požela - 10, S. Digrys - 3, S. Kairys - 2, J. Plečkaitis - 1 kartą ${ }^{60}$. Pateikta statistika leidžia konstatuoti, kad socialdemokratai debatuose dèl Konstitucijos turinio dalyvavo tikrai itin aktyviai.

Kalbant apie nuolatinės Konstitucijos projekto svarstymą, savaime suprantama, kad valstybės valdžios sąrangos, struktūros, įstatymų leidžiamosios ir vykdomosios valdžios santykio, šių institucijų funkcijų ir kompetencijų klausimai buvo vieni iš p. 1-2; 192103 10, Nr. 10(59), p. 1-2; 192103 24, Nr. 12(61), p. 1; 192103 31, Nr. 13(62), p. 1.

58 Kašauskienè, V., supra note 5, p. 91-92.

59 Ibid., p. 92.

60 Ibid. 
svarbiausių ir natūralu, kad dèl jų vyko aštrūs ginčai. Ir vèlgi socialdemokratai ir toliau aršiai ir atkakliai pasisake prieš prezidento instituciją.

1922 m. vasario 24 d. pirmą kartą svarstant St. Seimo komisijos parengtą Lietuvos Konstitucijos projektą, V. Čepinskis pažymėjo, kad prie skyriaus apie Seimą jis „nieko neturi pridèti“, jo požiūriu, skyrius „yra gana gerai suredaguotas, atatinka demokratybės principams" ${ }^{\text {"61 }}$. Tačiau su Konstitucijos projekte siūlomu vykdomosios valdžios „sutvarkymu“ V. Čepinskis nesutiko. Savo labai ilgoje kalboje, kuriai buvo būdingi istoriosofiniai bei politiniai teoriniai ekskursai, V. Čepinskis dar kartą pasisakè prieš prezidento institucijos įvedimą Lietuvoje ${ }^{62}$.

Savo kalboje (kaip ir $1921 \mathrm{~m}$. straipsnyje „Ar mums reikia prezidento?"), V. Čepinskis akcentavo, kad prezidento institucijos galios pasaulyje mažèja, kad atsiradę kaip „monarchų paveldètojai“ arba kaip jų (monarchų) „surogatai“, „prezidentai turèjo monarchų atributų“, kurie tačiau „einant kovai už politinę laisvę vis labiau ir labiau buvo mažinami“ ir kad „šiandien visų respublikų prezidentai“ tèra „monar-

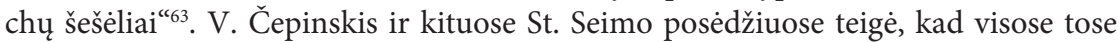
respublikose, kur yra prezidentai, jų kompetencijos varžomos vis labiau ir labiau ${ }^{64}$.

İdomu tai, kad minètoje kalboje (1922 02 24) V. Čepinskis ypač pasisake prieš parlamente renkamą prezidentą. Jis kalbëjo, jog ten, „kur yra tikrai demokratinè respublika, kur nèra toks mišinys kaip pas mus (...), tai ir prezidentas, ir teismas, ir visi valdininkai yra liaudies renkami“ ir kad „taip yra iš dalies Amerikoje ir Šveicarijoje“. Toliau V. Čepinskis jau tik savo, o ne LSDP frakcijos vardu pažymèjo, jog jis „dar suprastų galingą prezidentą, jeigu liaudis tą prezidentą rinktų, bet kada parlamentas renka, kada renkant derybos ir kompromisai turi didžiausios reikšmès, tai (...) tas visai nesuprantama ${ }^{\text {“65. }}$.

V. Čepinskis pabrèžè, kad „ypatingai kunigai labai karštai stovi už prezidentą“ ir kad tai yra „suprantama, nes pas juos autokratinis principas yra pravestas iki galui, o autonomingas principas pirmykščios krikščionybès, principas pirmụjų autonominių krikščionių komunų yra visiškai išnykęs". Kadangi kunigams, pasak V. Čepinskio, „viešpatauja autokratinis principas, tai jie nuo to ir pasauliniame (pasaulietiniame G. M.) gyvenime jokiu būdu pasiliuosuoti negali ir todèl jie čia ir siūlo prezidentą". Nors iš tiesų, V. Čepinskio nuomone, jiems (t. y. kunigams - G. M.) „daug labiau patiktų karalius, o ne prezidentas“, kuris ,jiems masonų išmislas“ ir jie (kunigai) „,su mielu noru čia pasiūlytų karalių arba kunigaikštị, bet nedrịsta"66.

Ir kituose St. Seimo posėdžiuose, kur buvo svarstomas nuolatinès Konstitucijos projektas, V. Čepinskis savo kalbose akcentavo, jog noras ịvesti Lietuvoje prezidento

61 Steigiamojo Seimo darbai. 176 p-dis, 192202 24, p. 82.

62 Ibid., p. 81-83.

63 Ibid., p. 82.

64 Žr. Steigiamojo Seimo darbai. 184 p-dis, 192203 17, p. 55.

65 Steigiamojo Seimo darbai. 176 p-dis, 192202 24, p. 82.

66 Ibid., p. 83. 
instituciją laikytinas „monarchijos rudimentu“, kad šis noras turèti prezidentą yra susijęs su tuo, kad „pas mus stipriai veikia monarchinès ir dvarininkų politinès tradicijos“, kad šios tradicijos matosi iš tų Konstitucijos projekto pataisų, kurias teikia „dešinioji puse““ ir kurios „dalinai yra priimtos“"67. Tai, anot V. Čepinskio, „sudaro galimybes tam, kad prezidentas gali lengvai igyti tokias ypatybes ir tokius apetitus, kad kokiais nors būdais sustiprinti savo poziciją ir padaryti ją stipresnę negu kad leidžia konstitucija“"68. Pasak V. Čepinskio, tai parodo krikščionių demokratų bloko daugumos St. Seime norą „palaikyti personalinį valstybès supratimą “ bei norą „prieiti prie „krulio“69.

Tai, kad St. Seimo daugumos noras ịvesti Lietuvoje prezidento instituciją sietinas su jos (St. Seimo daugumos) atstovavimu „apskritai buržuazinèms partijoms būdinga konservatizmo ir absoliutizmo tradicija“, tvirtino ir antrasis iš pagrindinių šalia V. Čepinskio socialdemokratų frakcijos St. Seime kalbėtojų, vienas tarpukario laikotarpio LSDP lyderių K. Bielinis. Anot jo, tik dèl to, „kad dabar yra toks laikas, kad to absoliutizmo negalima parodyti“ ir dèl to, kad „Uracho pasiūlymas yra negalimas“, St. Seimo dauguma ir „siūlo nors prezidentą “70. LSDP frakcijos seniūnas K. Venclauskis vienoje savo kalbų prieš prezidento instituciją taip pat tvirtino, kad „vienas didžiausių buvusio prezidento (turimas mintyje A. Smetona - G. M.) norų buvo, kad čia (Lietuvoje - G. M.) būtų monarchija“, kad „prezidento institucijos nori tie, kurie norejo [„sieke"] Uracho"

Nuolatinès Konstitucijos projekto svarstyme dalyvavusių socialdemokratų nuomone, dèl prezidentų siekimų igyti vis didesnę valdžią bei su prezidento institucijos egzistavimu susijusių galimų intrigų prezidento institucija apskritai yra pavojinga demokratijai.

Štai K. Bielinis 1922 m. liepos 14 d. St. Seimo posèdyje pasisakydamas prieš prezidento instituciją tvirtino, kad dèl galimo prezidento siekimo igyti vis didesnę valdžią ir dèl to galimo „ejjimo ị absoliutizmą“ bei galimo „monarchizmo ir absoliutizmo" susiformavimo pavojų „prezidento institucija sukelia pavojų demokratijai" ${ }^{\text {"72. }}$.

Toki pavojų K. Bielinis j̨žvelgè iš nuolatinès Konstitucijos projekto teksto atsirandančioje galimybejje, jog tarp Seimo rinkimų valstybè gali 60 dienų egzistuoti be Seimo. Dar anksčiau, 1922 m. kovo 17 d. St. Seimo posėdyje, K. Bielinis teigé, jog apskritai „ịvedimas prezidentūros varžo demokratijos teises, nes Seimas tokiu būdu perleidžia dalį savo teisių atskiram žmogui - prezidentui"“73. Pavojų demokratijai ir „ejjimą i absoliutizmą“ K. Bielinis įžvelgè net ir dèl prezidentui suteiktos teisès pasi-

67 Steigiamojo Seimo darbai. 218 p-dis, p. 94; 184 p-dis, 192203 17, p. 55.

68 Steigiamojo Seimo darbai. 184 p-dis, 1922 0317, p. 55.

69 Steigiamojo Seimo darbai. 218 p-dis, p. 93.

$70 \quad$ Steigiamojo Seimo darbai. 184 p-dis, 192203 17, p. 57.

71 Steigiamojo Seimo darbai. 185 p-dis, 192203 22, p. 63.

72 Steigiamojo Seimo darbai. 224 p-dis, 192207 14, p. 99, 101.

73 Iš St. Seimo. Socialdemokratas. 192203 23, Nr. 12, p. 2; Steigiamojo Seimo darbai. 184 p-dis, 192203 17, p. 56-58. 
rašyti tarpvalstybines sutartis bei dèl numatomo prezidentui vyriausiojo ginkluotųju pajègų vado statuso.

Dar kategoriškiau tokią poziciją išreiške V. Čepinskis. 1922 m. liepos 12 d. jis St. Seimo posėdyje pareiškè, jog „respublikoj prezidentas yra antidemokratingas asmuo, antidemokratinga institucija ${ }^{\text {" } 74}$. V. Čepinskis kalbèjo taip: „Kadangi Lietuvos Respublika yra demokratinè respublika, (...) o mes socialdemokratai esame jos šalininkai, tai mes balsuosim už tai, kad respublikos prezidentas būtų pakeistas Seimo pirmininku."

Savo argumentą, esą prezidento institucija kelia pavojų demokratijai, nes sudaranti galimybes vienam asmeniui igyti vis daugiau ir daugiau valdžios bei sudaranti prielaidas reikštis demokratijai pavojingoms intrigoms, socialdemokratai (kaip ir 1920 m. svarstant laikinosios Konstitucijos projektą) motyvavo ir neigiama, pasak jų, 1919 m. patirtimi. Nuolatinès Konstitucijos projekto svarstymuose socialdemokratai ne kartą išsakè neigiamą požiūrị i 1919 m. Lietuvos prezidento institucijos funkcionavimo praktiką, kuri, pasak jų, skatinusi ịvairias nedemokratiškumo, antidemokratiškumo ir ịvairių intrigų apraiškas ${ }^{75}$.

K. Bielinis kalbejjo, jog Lietuvoje 1919 m. „dejjosi tokie dalykai, kad šiaip ar taip demokratija buvo įžeista"76. K. Bielinis prisiminė Valiukų sušaudymo bylą ir kèlè retorinius klausimus, „ar ne prezidentas padejo po stalu“ šio sušaudymo bylą, „ar ne prezidentas savo autoritetu ir savo galia paslèpe žulikus, užmušèjus ir žmogžudžius?“. K. Bielinis pats ị šiuos retorinius klausimus ir atsakè - „tą padarè prezidentas“, kuris, pasak socialdemokrato, „pridengé nuo teismo“ žudikus, kurie minimos kalbos sakymo metu, anot Bielinio, jau buvo pasitraukę iš Lietuvos. K. Bielinis buvusį prezidentą A. Smetoną kaltino ir „valstybès lèšų“ - „Lietuvos liaudies pinigų“ švaistymu („dovanojimu").

Savo $1922 \mathrm{~m}$. kovo 22 d. St. Seime pasakytoje kalboje V. Čepinskis irgi panaudojo neigiamos 1919 m. - $1920 \mathrm{~m}$. pradžios prezidento institucijos patirties argumentą, teigdamas, jog „buvęs respublikos prezidentas“, kurị jis (V. Čepinskis - G. M.) „pažistąs nuo gimnazijos laikų“, nors ir "geras žmogus“, tačiau ịsivaizdavo sau, kad jis yra ypatingas Viešpaties parinktas žmogus, taip sakant pateptas žmogus dèl tos priežasties, kad buvo Prezidentas, tiesiog susirgo ir ... pridare daug žalos valstybei..." ${ }^{\text {"77. }}$.

St. Seimo posèdžiuose pasisakydami prieš prezidento institucijos įvedimą Lietuvoje, socialdemokratai atmetè ir dešiniụjų teikiamus argumentus dèl šios institucijos reikalingumo. Štai atsakydamas ị prezidento institucijos šalininkų argumentą, kad ši institucija reikalinga, „nes reikia skirti ir išskirti visos vykdomosios valdžios funkcijos“, V. Čepinskis vienoje savo kalbų pabrěžè, jog prezidento institucija „visai neatsako konstitucijos prasmei demokratintųjų valstybių, kaip ji faktinai apsireiškia"78.

74 Steigiamojo Seimo darbai. 222 p-dis, 1922 0712, p. 60.

75 Steigiamojo Seimo darbai. 184 p-dis, 192203 17, p. 57; 185 p-dis, 1922 03 22, p. 60, 63; 224 p-dis, 192207 14, p. 100.

76 Steigiamojo Seimo darbai. 184 p-dis, 192203 17, p. 57.

77 Steigiamojo Seimo darbai. 185 p-dis, 192203 22, p. 60.

78 Steigiamojo Seimo darbai. 184 p-dis, 192203 17, p. 55. 
Pasak V. Čepinskio, „šiandien demokratinèse valstybėse vykdomos valdžios funkcijos ir ịstatymų leidimo funkcijos susiduria ir būna kontakte“. Kaip to pavyzdys buvo nurodyta Anglija, kur „taip yra kad kai kurios vykdomosios valdžios funkcijos neišeina iš parlamentų rankų“. V. Čepinskis kritikavo, anot jo, nerimtą argumentą, esą prezidento institucija yra reikalinga dèl to, kad Lietuvoje nesant antrųjų aukštesniųjų parlamento rūmų, kurie tobulintų ir siūlytų taisyti parlamento leidžiamus istatymus, tai galįs padaryti prezidentas.

Tačiau, V. Čepinskio nuomone, „praktika parodè, kad prezidentai ir antrieji rūmai ịstatymus ne tobulina, bet gadina“, todèl, V. Čepinskio teigimu, „jeigu mes priimsime prezidentą, tai mūsų ịstatymus tik tai gadins ir daugiau nieko“. Prieš prezidento veto teisès Seimo priimtų ịstatymų atžvilgiu reikalingumą pasisakè ir kiti LSDP frakcijos atstovai ${ }^{79}$.

Savo kalbose V. Čepinskis atmetè ir trečią jo oponentų argumentą, esą be prezidento negalima apsieiti tuo metu, kai „nèra Seimo“80. Jis teigé, kad šis „argumentas irgi neišlaiko kritikos“, nes Lietuvoje „buvo keli atsitikimai, kada nebuvo Seimo, Seimas buvo atostogose, o vis dèlto Lietuva nesugriuvo...“.

Kaip ir svarstant laikinosios Konstitucijos projektą, debatuose dèl nuolatinès Konstitucijos projekto LSDP frakcijos St. Seime nariai kaip argumentą prieš prezidento institucijos Lietuvoje ịvedimą naudojo ir tvirtinimą, jog ši institucija Lietuvai yra per brangi ${ }^{81}$. V. Čepinskio tvirtinimu, prezidento institucija „suima iš mūsų šalies daug pinigų, o mūsų kraštas nepriskiriamas prie turtingiausių “82.

1922 m. liepos 12 d. St. Seimui trečią kartą svarstant nuolatinès Lietuvos Respublikos Konstitucijos projektą, K. Bielinis vèl iškèlè „finansinį motyvą“ prieš prezidento institucijos ịvedimą. K. Bielinis kalbejo: „Jeigu dabar Steigiamasis Seimas turi laikiną Prezidentą - einantị Prezidento pareigas, tai reprezentacijos išlaidos ir visoks kitoks išlaikymas yra vis dèlto vieno žmogaus išlaikymas, bet jei bus atskiras Respublikos prezidentas ir jei bus elgiamasi taip monarchiniai, kaip tiems prezidentams kartais reikalinga, tai galima ịsivaizdinti, kad tas dešimtimis milijonų kvepia. Juk prezidentas, aš manau, nevažiuos valstiečių ratuose, porą kumelių pasikinkęs reikès automobilio, arklių, reikalingi bus tarnai ir livrejjos... Aš esu tikras, kad tais pinigais, kuriuos mes išleisim ì penkerius metus prezidentui laikyti, mes galètum ịsteigti gal ūkio akademiją, kur mūsų valstiečiai, dideli nuosavybės mylètojai ... galètų pasimokyti, kaip vesti ūkị ir kartu savo gyvenimą pagerinti. Aš manau, kad finansinis išrokavimas čia yra labai didelis. Jei jị paversim ị kitas vertybes, tai tos vertybės mūsų mažam kraštui labai daug atsvertų. Todèl mes visai nesuprantam, kam reikalingas prezidentas?..." ${ }^{\text {"83 }}$

79 Steigiamojo Seimo darbai. 185 p-dis, 192203 22, p. 67, 75.

80 Steigiamojo Seimo darbai. 184 p-dis, 192203 17, p. 55.

81 Ibid.; Steigiamojo Seimo darbai. 222 p-dis, 192207 12, p. 61.

82 Steigiamojo Seimo darbai. 184 p-dis, 1922 0317, p. 55.

83 Steigiamojo Seimo darbai. 222 p-dis, 1922 0712, p. 61. 
Kadangi prezidento institucija, be to, kad riboja Seimo teises ir kelia pavoju demokratijai, yra dar ir per brangi, tai, pasak socialdemokratų, visas tas prezidento pareigas, kurias numate nuolatinès Konstitucijos projektas, gali atlikti ir Seimo pirmininkas ${ }^{84}$. Svarstant nuolatinès Konstitucijos projektą socialdemokratai pateikè argumentą, jog Lietuva dvejus metus neturejjo prezidento, o tik Seimo pirmininką, laikinai einanti prezidento pareigas, ir kad ji ir toliau gali apsieiti be specialaus prezidentūros instituto ${ }^{85}$.

Nuolatinès Konstitucijos ịstatymo projekto svarstymuose socialdemokratai fiksuojamą nuostatą „Valstybės vyriausybę sudaro: Respublikos Prezidentas ir Ministerių Taryba“ siūlè pakeisti ị formuluotę: „Lietuvos Respublikos vyriausybę sudaro Seimo pirmininkas ir Ministerių Taryba" ${ }^{86}$.

Be to, vietoj nuolatinio „prezidento rinkimo“ socialdemokratų frakcija prezidentui numatomas pareigas pavesti eiti Seimo pirmininkui siūle ir 3-ioje pataisoje savo 18-os Konstitucijos pataisų pakete, pateiktame $1922 \mathrm{~m}$. vasarą prasidejusiam trečiajam Lietuvos Respublikos Konstitucijos projekto svarstymui ${ }^{87}$. Šioje pataisoje taip pat buvo prieštaraujama ne tik atskiros prezidento institucijos įsteigimui, bet ir krikščionių demokratų numatytoms prezidento teisèms, pavyzdžiui, prezidento veto teisei grąžinti Seimui persvarstyti Seimo priimtus ịstatymus.

Tačiau St. Seimui 1922 m. liepos 14 d. trečio svarstymo metu papunkčiui balsuojant už atskirus nuolatinès Konstitucijos projekto paragrafus, už minètą socialdemokratų formuluotę, kas sudaro vyriausybę, bei analogišką valstiečių liaudininkų bloko pataisą balsavo 30 St. Seimo narių, o prieš šią pataisą pasisake 57 St. Seimo nariai ${ }^{88}$. Balsuojant už Konstitucijos projekto paragrafus, numatančius prezidento instituciją ir nurodančius jo teises, socialdemokratai, kaip ir valstiečiu liaudininkų frakcija, išejo iš posėdžių salès ${ }^{89}$. Tačiau krikščionių demokratų blokas kartu su dalimi žydų frakcijos surinko reikalingą balsų daugumą ir „vieni patys" priemė paragrafą apie prezidento teises ${ }^{90}$. Taigi buvo atmesta ir socialdemokratų teikta pataisa, reikalaujanti panaikinti (išbraukti) visus tuos Konstitucijos paragrafus, kur buvo kalbama apie nuolatinio prezidento teises ir jo rinkimo būdus ${ }^{91}$.

Socialdemokratai teige, kad „krikščionys“ suteike prezidentui „tokias teises, kurias ne visi karaliai turi“, ir tai ịvertino griežtai neigiamai, itin reikšdami nepasitenkinimą tokia prezidento teise, kaip „teisé paleisti Seimą ir jo nešaukti du mènesius“,

Steigiamojo Seimo darbai. 176 p-dis, 192202 24, p. 82-83; 184 p-dis, 192203 17, p. 55; 185 p-dis, 192203 22, p. 62-63; 222 p-dis, 192207 12, p. 60-61, 72.

85 Steigiamojo Seimo darbai. 176 p-dis, 192202 24, p. 82-83; 185 p-dis, 1922, 03 22, p. 62-63.

86 Steigiamojo Seimo darbai. 184 p-dis, 192203 17, p. 55; 224 p-dis, 1922 0714, p. 94.

87 Socialdemokratų frakcijos pataisos teikiamos III Lietuvos Konstitucijos svarstymui. Socialdemokratas. 192207 20, Nr. 29, p. 1.

88 Steigiamojo Seimo darbai. 224 p-dis, 1922 0714, p. 96.

89 Ibid.

$90 \quad$ Ibid., p. 97.

91 Socialdemokratų frakcijos pataisos teikiamos III Lietuvos Konstitucijos svarstymui, supra note Socialdemokratas. 192207 20, Nr. 29, p. 1. 
kurią traktavo kaip „grynai rusų caro laikų pavyzdį ${ }^{\text {“92 }}$. Prezidento institucijos ịvedimą bei jam suteiktas teises socialdemokratai traktavo kaip „liaudies vyriausiųjų teisių užgrobimą“, kaip „Lietuvos klerikalų, stambiųjų ūkininkų ir buržuazijos norą sustiprinti savo padètị ir ginti savo reikalus jų statomo prezidento pagalba" ${ }^{\text {“93 }}$.

Baigdami pristatyti socialdemokratų argumentus prieš prezidento instituciją ir žvelgdami ị juos iš šiandienos politikos teorijos ir politinès praktikos pozicijų, matyt, galime teigti, kad aptariamo laikotarpio Lietuvos socialdemokratai tikrai akivaizdžiai neadekvačiai ir hipertrofuotai vertino St. Seimo komisijose parengtuose laikinosios ir nuolatinés konstitucijų projektuose numatytas prezidento institucijos galias.

Matyt, galime sutikti su istorikès V. Kašauskienès tvirtinimu, jog nuolatinès Konstitucijos prièmimo procese socialdemokratai, kaip ir 1919-1920 m., „vis dar pernelyg jautriai reagavo ị tariamas monarchizmo įsigalejjimo grèsmes “94. Pritartina ir istorikès vertinimui, jog LSDP frakcijos atstovų pataisas ir pasiūlymus dèl atskirų Konstitucijos projekto straipsnių galima apibūdinti „griežtai apibrěžta radikalia nuostata - besąlygišku "grynosios“ demokratijos stiprinimu ir gynimu“"95. Tai pasakytina ne tik apie socialdemokratų nuostatas dèl prezidento institucijos, bet ir apie kitas konstitucines jų nuostatas.

\section{Socialdemokratų frakcija nuolatinès Lietuvos Respublikos Konstitucijos projekto svarstymo procese $1922 \mathrm{~m}$. (II): kitos radikaliai demokratinès nuostatos}

St. Seimo socialdemokratų frakcijos orientaciją i besąlygišką "grynosios“ demokratijos stiprinimą ir gynimą" patvirtintų ir nuolatinis socialdemokratų pasisakymas už tai, kad Seimo rinkimai vyktų ne kas treji, kaip buvo siūloma nuolatinès Konstitucijos projekte, o kas dveji metai ${ }^{96}$. Žinomas ne tik kaip mokslininkas, bet ir kaip pedagogas V. Čepinskis savo pasisakymuose St. Seime pabrěžė pedagoginę arba auklejamąją dažnai vykstančių Seimo rinkimų reikšmę, pasak jo, dažni rinkimai neleis Seimo „nusistatymui“ atitrūkti nuo krašto „nusistatymo “97.

V. Čepinskis kalbejo, jog „agitacija ypatingai tarp žmonių šalto kraujo, kuo lietuviai mégsta dažnai pasigirti, yra labai naudingas daiktas“ ir net „perdejimas (agitacijoje - G. M.) kai kuriais atvejais taip pat gali būti naudingas“, ir kad „vienintelè priemonè politiniai auklèti mūsų liaudi yra mitingai, surišti su ịvairiais politiniais rinkimais“. V. Čepinskis atmetė argumentą, esą dažni rinkimai valstybei per daug

Krikščionys ir konstitucija. Socialdemokratas.1922 07 20, Nr. 29 (129), p. 1; Socialdemokratų frakcijos deklaracija del konstitucijos įstatymo. Socialdemokratas. 192208 03, Nr. 31, p. 1.

94 Kašauskienè, V., supra note 5, p. 92.

95 Ibid.

96 Steigiamojo Seimo darbai. 184 p-dis, 192203 17, p. 47; 218 p-dis, p. 94; 222 p-dis, 1922 0712, p. 59-61. 
kainuojantys, ir tvirtino, kad Seimo „perrinkimas kas 2 metai pigiau kaštuos respublikai“. Didelę pedagoginę dažnų rinkimų reikšmę visuomenès „politiniam auklejjimui“ akcentavo ir antrasis iš dviejų pagrindinių socialdemokratų oratorių St. Seimo posèdžiuose K. Bielinis ${ }^{98}$.

St. Seime svarstant savivaldybių tarybų rinkimų i̇statymą LSDP frakcijos atstovai taip pat pasisakè už tai, kad ir savivaldos institucijos būtų renkamos ne trejiems, bet dvejiems metams ${ }^{99}$, taigi, kad būtų palikta lig tol galiojusi savivaldybių kadencijos trukmé. Tačiau šis siūlymas, kaip ir siūlymas rengti Seimo rinkimus kas dveji metai, kaip ir tuo pagrindu siūloma Konstitucijos projekto pataisa ${ }^{100}$, buvo St. Seimo daugumos atmesti.

Pažymėtina, kad socialdemokratai, priimant ir $1920 \mathrm{~m}$. birželio 2 d. laikinąją Konstituciją, ir $1922 \mathrm{~m}$. nuolatinę Konstituciją pasisakè už tai, kad ministrais gali būti tik Seimo nariai. Štai 1922 m. vasario 24 d. St. Seimo posèdyje V. Čepinskis kalbejjo, jeigu prisilaikoma „parlamentarinès tvarkos, tai reikia skirti ministerius iš Seimo narių tarpo“ ir kad toks „ministerių paskyrimo būdas labiau atatiktų mūsų Konstitucijos dvasiai ir būtų nuoseklesnis ir naudingesnis "101. Kada to nèra, tai, pasak V. Čepinskio, nèra „ankštaus organinio ryšio tarp Seimo ir valdžios“ ir tada „gali išeiti daug tokių nesusipratimų, kurių pasekmès gali būti žalingos visuomenei“. Tačiau minimam LSDP frakcijos siülymui Konstitucijos projektui, kaip ir daugeliui kitų jų pasiūlymų ir pataisų, St. Seimo dauguma nepritarè.

Teiginį, kad St. Seimo LSDP frakcija pasisakè už itin radikalią demokratinę parlamentinę valdymo formą, galime paremti ir tuo, jog Konstitucijos priemimo procese socialdemokratai, pasisakydami už „teismų nepriklausomybę" ir nuo vyriausybės, ir nuo Seimo, buvo už tai, kad teisejjai „būtų liaudies renkami ir jos mainomi“ ${ }^{“ 102}$. Socialdemokratų požiūriu, nuostata, kad teisèjai turi būti liaudies renkami, išplaukè „iš liaudies suverenių teisių“. LSDP frakcijos tvirtinimu, „tai svarbus reikalavimas, nes tik tuomet, kada teismas priklauso nuo liaudies, jisai bus greitas ir teisingas".

Reikètų paminèti, kad socialdemokratai ypač kategoriškai pasisake prieš ypatinguosius ir karo lauko teismus ${ }^{103}$. LSDP frakcija teike Konstitucijos projekto pataisą, kurioje reikalavo, kad būtų itvirtinta nuostata, jog „Teismas yra visiems piliečiams lygus" ir kad „visus piliečius turi teisti vienas teismas ir jokių ypatingų teismų kariams

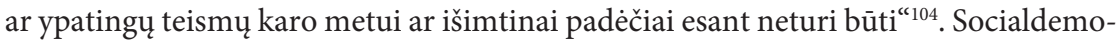

98 Supra note 97.

99 Steigiamojo Seimo darbai. 57 p-dis, 192101 25, p. 553; 71 p-dis, 192103 11, p. 801-802.

100 Socialdemokratų frakcijos pataisos teikiamos III Lietuvos Konstitucijos svarstymui, supra note 87,p. 1.

101 Steigiamojo Seimo darbai. 176 p-dis, 192202 24, p. 83.

102 Steigiamojo Seimo darbai. 227 p-dis, 192207 20, p. 56-57, 59; Socialdemokratų frakcijos pataisos teikiamos III Lietuvos Konstitucijos svarstymui, supra note 87, p. 1.

103 Steigiamojo Seimo darbai. 193 p-dis, 192204 05, p. 39, 40-41.

104 Socialdemokratų frakcijos pataisos teikiamos III Lietuvos Konstitucijos svarstymui, supra note 87 , p. 1. 
kratas J. Plečkaitis, pasisakydamas prieš tokius teismus, tvirtino, jog „socialdemokratų partija savo esmejje yra giliai demokratinga partija“ ir kad „jai nesvarbu, ar šiandien yra krikščionių demokratų partijos dauguma, ar kokia kita dauguma bus“, ji „visuomet sutinka su civiliniais teismais, kurie baustų už peržengimą įstatymų, bet socialdemokratų partija nesteigè ir nesteigs ypatingųjų teismų savo priešininkams" ${ }^{\text {"105. }}$.

Tai, kad pataisos prieš karo lauko ir ypatinguosius teismus buvo atmestos, LSDP frakcija savo pareiškime dèl Konstitucijos priemimo laike kaip „Lietuvos turtingųjų luomų, buržuazijos ir reakcinių grupių“ norą „aštrios socialinès kovos metui pasidaryti iš teismų klusnų jiems ịrankį klasiniams jų interesams apdrausti “106.

Matyt, galime pritarti istoriografijoje išsakytam vertinimui, kad „tokị kategorišką LSDP frakcijos požiūrị i teismų organizaciją nulèmé ne vien socialdemokratijos bendrosios politinès nuostatos bei ideologinè doktrina, bet ir baimé, kad jie netaptu Seimo daugumos teismais, priklausomais nuo įstatymų leidžiamosios ir vykdomosios valdžios" ${ }^{\text {"107 }}$.

Kalbant apie St. Seimo socialdemokratų konstitucines nuostatas, susijusias su teisingumo vykdymo sfera, reikètų taip pat paminèti, kad jie siūle Konstitucijos projekto pataisą, kuria buvo reikalaujama, kad „neteisingai nuteistieji ir kalinami gautu atlyginimą iš valstybès lèšų“. Jų nuomone, tokių atsitikimų gali būti, todèl „neteisingai nuteistasis turi gauti atlyginimą ne tik moralinị, bet ir medžiaginị “108.

Socialdemokratai pasisakè prieš bet kokị, tegu ir laikiną Konstitucijos garantijų sustabdymą. Pavyzdžiui, svarstant Konstitucijos projekto straipsnị, kuriame buvo sakoma, jog „kilus karui, ginkluotam sukilimui ar kitokiems neramumams valstybèje Ministrų Tarybai pasiūlius, Respublikos prezidentas gali visoj valstybejj arba tam tikrose jos dalyse paskelbti karo arba kitą nepaprastą padètị“, socialdemokratai tiek savo pasisakymuose, tiek pataisoje Konstitucijos projektui reikalavo išbraukti žodžius „,ir kitokiems neramumams“, nes tais „kitokiais neramumais“ valdžia, pasak socialdemokratų, „gali paskaityti ir ramiausius streikus, ir ịvesti karo padetį ${ }^{\prime 109}$.

Minètoji atitinkamo Konstitucijos straipsnio formuluote socialdemokratams buvo nepriimtina ir dèl to, kad joje nebuvo pasakyta tai, „kaip ilgai tas Prezidento (socialdemokratai, kaip matėme, siekè, kad vietoj žodžio „Prezidentas“ būtų įrašyta žodžiai „Seimo pirmininkas“ - G. M.) aktas dèl karo ar išimtinos padèties paskelbimo galioja" ir reikalavo, kad Konstitucijoje būtų numatyta tai, jog kilus karui ar ịvedus nepaprastąją padètị, „laike trijų dienų būtų sušauktas Seimas”, kuris šiais klausimais priimtų galutinius sprendimus ${ }^{110}$.

105 Steigiamojo Seimo darbai. 193 p-dis, 192204 05, p. 41.

106 Socialdemokratų frakcijos deklaracija del konstitucijos ịstatymo, supra note 92, p. 1.

107 Kašauskienè, V., supra note 5, p. 95.

108 Socialdemokratų frakcijos pataisos teikiamos III Lietuvos Konstitucijos svarstymui, supra note 87, p. 1.

109 Ibid.; Steigiamojo Seimo darbai. 223 p-dis, 1922 0713, p. 72.

110 Ibid. 
Pažymėtina ir tai, jog socialdemokratų frakcija, kaip ir valstiečiu liaudininkų blokas, reikalavo, kad Konstitucijoje būtų užfiksuota spaudos laisvè, kad būtų fiksuota nuostata, draudžianti cenzūrą ${ }^{111}$.

Kaip ir svarstant 1920 m. laikinosios Konstitucijos projektą, svarstant 1922 m. nuolatinès Konstitucijos projektą, socialdemokratai pasisakė už mirties bausmès panaikinimo užfiksavimą Lietuvos Respublikos Konstitucijoje ir kaltino nenoru tai padaryti krikščionis demokratus ${ }^{112}$. Savo kalboje $1922 \mathrm{~m}$. vasario $24 \mathrm{~d}$. V. Čepinskis pabrèžè, kad mirties bausmė yra „ne tik senovés liekana, bet ir baisi barbariška liekana“, kuri „ar taikos, ar karo metu yra vienas iš bjauriausių ir kenksmingiausių apsireiškimų žmonių gyvenime“, kad „mes socialdemokratai, skaitome teisę gyventi pagrindine ir neliečiama žmogaus teise“. V. Čepinskiui buvo „nesuprantama“, kodèl „save krikščionišku vadinančiame“ ir „visuomet krikščionybę pabrěžiančiame mūsų krašte“ „kenčiamas toks dalykas kaip mirties bausmé“"113.

1922 m. vasarą trečią kartą svarstant nuolatinès Konstitucijos projektą V. Čepinskis griežtai kritikavo krikščionių demokratų bloką už tai, kad iš nuolatinès Konstitucijos projekto buvo išbrauktas mirties bausmę panaikinantis straipsnis, kas, anot šio socialdemokrato, reiškè, jog „imant domèn mūsų visuomenès nusistatymą, aišku, kad ta bausmé bus vartojama“, nepaisant to, jog ji kaip „priemonė kovai su antivisuomeninio nusistatymo gaivalais yra ne tik priešinga krikščioniškai dorai, apie kurią mègsta kalbèti dešinioji klerikalinè pusè (...), bet ir praktikoje neduoda jokios naudos ${ }^{\text {"114 }}$. Konstitucijos projekto trečiajame svarstyme socialdemokratai pačia pirmąja pataisa sieke ị Konstitucijos tekstą ịtraukti žodžių junginį „Mirties bausmé panaikinama" ${ }^{115}$, tačiau to socialdemokratams pasiekti nepavyko.

Socialdemokratai tai ịvertino itin kritiškai. „Socialdemokrate" buvo rašoma, kad remiantis nuostata, „ko įstatymas nedraudžia, tai leidžia“, „išmetimas to punkto iš Konstitucijos yra lygus mirties bausmès ịvedimui“ ir kad „tariamieji Kristaus mokslo skelbẻjai, mokyti teologijos daktarai tokiu būdu atmesdami siūlomąją pataisą atmainé penktąji Dievo įsakymą „Neužmušk" ${ }^{116}$. LSDP frakcijos pareiškime nuolatinès Konstitucijos prièmimo dieną buvo pažymèta, kad neužfiksuodama mirties bausmès panaikinimo „krikščioniškoji Seimo dauguma nulèmè, kad socialinè ir politiné kova būsimoj Lietuvoje, sprendžiama Lietuvos teismuose, galès pasigauti kruvinų keršto priemonių"117.

111 Žr. Steigiamojo Seimo darbai. 182 p-dis, 192203 14, p. 8-1,13-16.

112 Steigiamojo Seimo darbai. 176 p-dis, 192202 24, p. 8-81; 181 p-dis, 192203 10, p. 81-84, 89-91.

113 Steigiamojo Seimo darbai. 176 p-dis, 192202 24, p. 80-81.

114 Steigiamojo Seimo darbai. 218 p-dis, 192206 28, p. 93.

115 Socialdemokratų frakcijos pataisos teikiamos III Lietuvos Konstitucijos svarstymui, supra note 87, p. 1.

116 Krikščionys ir konstitucija, supra note 92, p. 1.

117 Socialdemokratų frakcijos deklaracija dèl konstitucijos įstatymo, supra note 92, p. 1. 
Radikalus socialdemokratų demokratizmas pasireiške ir tuo, kad jie, kaip ir 1920 m. laikinosios Konstitucijos prièmimo procese, griežtai pasisakė prieš luomus, privilegijas, titulus ir ordinus ${ }^{118}$. Anot V. Čepinskio, „ordenai ir atsižymèjimo ženklai yra papuošalas žmonėms labai paviršutinès sielos ir minčių“ ir kad jie „yra papuošalu žmonėms, kurie tuo papuošalu nori pridengti savo vidinę tuštumą ir daugiau nieko"119. Šis socialdemokratų reikalavimas taip pat nesulaukẻ kitų partijų atstovų pritarimo ir nebuvo įrašytas ị Konstituciją.

Konstitucijos prièmimo proceso metu LSDP frakcija kèlè taip pat tradicinị nuo pat savo veiklos pradžios programinị reikalavimą vietoj nuolatinès kariuomenès organizuoti „visos liaudies apginklavimą arba susiorganizavimą krašto gynimo milicijos pagrindais“, kad būtų ịvestas „visuotinis apmokinimas ginklą vartoti vietoj nuolatinès kariuomenès" ${ }^{120}$. Socialdemokratai siekè, kad Konstitucijoje būtų įrašyta nuostata: „Respublikai ginti organizuojamos ginkluotos pajègos milicijos pagrindais."121

Tokia pozicija buvo grindžiama tuo, kad mažiau bus išlaidų, kariuomenẻ bus arčiau žmonių, susitaupys daug pajègų, kurios nuolatinei kariuomenei esant veltui žūsta kareivinèse. Anot socialdemokratų, reikia skirti „visas pajègas krašto švietimo ir kultūros reikalams"122. Tai, kad ši pataisa buvo atmesta, socialdemokratai laikẻ krikščionių demokratų bloko noru iš „nuolatinės armijos viršūnių sudaryti sau palankią kariškių kastą"123.

LSDP frakcija siūlè pataisas ir švietimo klausimu. Ji siekė Konstitucijoje įtvirtinti nuostatą, jog pradžios mokslas yra „privalomas, nemokamas ir vedamas vaikų gimtąja kalba"124. Būsimasis Kauno universiteto prorektorius bei rektorius V. Čepinskis akcentavo „ne tiktai neatimamą, bet ir privalomą kiekvieno piliečio pareigą išsilavinti" ${ }^{125}$. Jis savo kalboje, pasakytoje pirmajame nuolatinès Konstitucijos projekto svarstyme, išreiškè nuomonę, jog Lietuvos Respublikai tam, „kad ji kultūros atžvilgiu būtų galinga, reikètų eiti prie to, kad visas mokslas visuose laipsniuose būtų nemokamas“, kad „reikètų padaryti visas mokyklas nemokamomis“.

V. Čepinskis siūlè padaryti taip, kad „mokslas būtų nemokamas pradedant nuo pradžios mokyklos ir baigiant universitetu, kad universiteto durys būtų atdaros ne tik turtingų valstiečių vaikams, bet ir mažažemių ir darbininkų vaikams (...) būtų puikiausias dalykas“, tai „būtų tikras pagrindas mūsų respublikos stiprumo ir laimès“.

118 Steigiamojo Seimo darbai. 176 p-dis, 192202 24, p. 82; 180 p-dis, 192203 08, p. 63, 67-71.

119 Steigiamojo Seimo darbai. 176 p-dis, 192202 24, p. 81.

120 Steigiamojo Seimo darbai. 196 p-dis, 192204 10, p. 117-120, 122-123; Iš St. Seimo, supra note 73, p. 3.

121 Socialdemokratų frakcijos pataisos teikiamos III Lietuvos Konstitucijos svarstymui, supra note 87, p. 1.

122 Iš St. Seimo. Socialdemokratas. 192204 20, Nr. 16, p. 3.

123 Socialdemokratų frakcijos deklaracija del konstitucijos ịstatymo, supra note 92, p .1.

124 Socialdemokratų frakcijos pataisos teikiamos III Lietuvos Konstitucijos svarstymui, supra note 87, p. 1.

125 Steigiamojo Seimo darbai.176 p-dis, 192202 24, p. 83. 
Reikia pažymèti ir tai, kad socialdemokratai pasisakè už mokyklos atskyrimą nuo Bažnyčios bei Bažnyčios atskyrimą nuo valstybès ir siekè tokią nuostatą užfiksuoti Konstitucijos tekste ${ }^{126}$. LSDP frakcija siekè, kad Konstitucijoje nebūtų nuostatos, jog „tikybos mokslas privalomas visose Lietuvos mokyklose“"127. Socialdemokratai pasisakè už tai, kad religijos mokymas būtų iškeltas iš mokyklos ir būtų paliktas tikybinèms organizacijoms ir šeimoms. Socialdemokratų frakcija neigiamai, su nedidele išimtimi, ịvertino privalomo tikybos dèstymo mokyklose ịvedimą ir laike tai „tèvų ir paaugusių mokinių sąžinės laisvès suvaržymu“"128. LSDP laikraštyje šio įstatymo bei Konstitucijos skyriaus apie „tikybos ir kulto dalykus“ priemimas buvo interpretuotas kaip „Lietuvos virtimas kunigų kastos respublika“129.

Socialdemokratai St. Seime taip pat gynè nuostatą, kad „mirties, gimimo ir vestuvių aktai būtų registruojami vietos savivaldybèse ir tuo būtų išimtis iš bažnyčios žinios", pasisake už tai, kad ši nuostata būtų ittraukta ị Konstituciją ${ }^{130}$. Jie buvo griežtai nusiteikę ir prieš tai, kad „bažnyčia būtų išnaudojama politinei agitacijai ir viešpatavimo tikslams" ${ }^{\text {"131 }}$.

Savo Konstitucijos projekto pataisose socialdemokratai taip pat siekè, kad tautinių mažumų piliečiai turètų „teises laisvai vartoti savo kalbą spaudoje, susirinkimuose, pareiškimuose valdžiai ir t. t., ir t. t.“. LSDP sieke „ịvykdinti visišką tautinių mažumų autonomiją (savivaldybę), tačiau nepripažino atskirų tautinių ministerijų Lietuvos Vyriausybejje. Tautines mažumas valdžioje (Ministrų kabinete) turẻjo atstovauti tų tautinių sąjungų vykdomųjų organų pirmininkai su sprendžiamuoju balsu tautiniuose klausimuose“132. Socialdemokratai neigiamai vertino Konstitucijos skyriaus apie tautinių mažumų teises turinį ${ }^{133}$.

\section{Socialdemokratų frakcija svarstant nuolatinès Lietuvos Respublikos Konstitucijos projektą (III): siekis ịtraukti ị Konstituciją socialinio ekonominio pobūdžio nuostatas}

Dar iki pirmojo nuolatinès Konstitucijos projekto Seime svarstymo socialdemokratų frakcija buvo įteikusi St. Seimo Konstitucijos komisijai iš 21 paragrafo sudarytą

126 Supra note 125, p. 84; 198 p-dis, 192204 18, p. 38; Socialdemokratų frakcijos pataisos teikiamos III Lietuvos Konstitucijos svarstymui, supra note 87, p. 1.

127 Steigiamojo Seimo darbai. 218 p-dis, p. 95.

128 Socialdemokratų frakcijos deklaracija del konstitucijos ịstatymo, supra note 92, p. 1.

129 Iš St. Seimo, supra note 73, p. 2.

130 Steigiamojo Seimo darbai. 218 p-dis, p. 95; Socialdemokratų frakcijos pataisos teikiamos III Lietuvos Konstitucijos svarstymui, supra note 87, p. 1.

131 Steigiamojo Seimo darbai. 218 p-dis, p. 95.

132 Socialdemokratų frakcijos pataisos teikiamos III Lietuvos Konstitucijos svarstymui, supra note 87, p. 1.

133 Socialdemokratų frakcijos deklaracija dèl konstitucijos įstatymo, supra note 92, p. 1. 
priedą „Ūkio skyrius“ prie rengiamo Konstitucijos projekto ${ }^{134}$. 1-ame minèto priedo paragrafe buvo įrašyta nuostata, kad „valstybė dalyvauja turtų paveldejjime esant tam tikrais ịstatymais“. 2-as paragrafas numate Konstitucijos nuostatą, kad „žemé, savininko neišdirbta ir neišnaudota, nusavinama, lygiai kaip ir žemé, reikalinga namų statybai dèl butų stokos arba žemès ūkio pakèlimui“. 3-iame paragrafe buvo siūloma „tokį žemès kainos padidejjimą, kuris neišeina iš darbo arba kapitalo ị ją ịdejjimo, nusavinti visuomenès reikalams“. 4-ame paragrafe buvo kalbama apie tai, kad „reikalui esant valstybė gali suvisuomeninti tas arba kitas privatines įmones einant tam tikrais istatymais".

5-ame paragrafe buvo numatoma, kad „valstybė imtų savo globon darbo jėgą ir tam tikrais įstatymais laiduotų darbo teisę“. LSDP frakcijos narių nuomone, kiekvienam žmogui turi būti suteikta darbo galimybè, „kad savo uždarbiu jis galètu pragyventi“. Tapus bedarbiu valstybè turèjo užtikrinti pragyvenimą „minimum normomis“. Nedarbo problemai spręsti buvo skirtas 6-as paragrafas, kuriame numatyta „planingai kovai su bedarbe, steigti darbo biržas, kurios registruotų bedarbius, sektų darbo rinkos stovị ir suteiktų informaciją apie ịvairius darbo pasiūlymus ir reikalavimus jiems“.

Socialinès apsaugos sistemai užtikrinti buvo skirtas 7-as socialdemokratų frakcijos teikto priedo Konstitucijai paragrafas, kuriame nurodoma, jog „darbininkų sveikatos ir darbingumo palaikymui, motinystès apsaugojimui, našlaičių, našlių ir senatvès aprūpinimui, lygiai kaip ir aprūpinimui nelaiminguose atsitikimuose, ligoje ir bedarbeje, valstybè sudaro draudžiamas (draudimo - G. M.) įstaigas dalyvaujant draudžiamiesiems“.

8-as paragrafas laidavo „visų fizinio ir proto darbo darbininkų koalicijos, organizacijos ir streiko teisę“. Taip pat šiuo paragrafu buvo panaikinamos visos galimos atskirų kategorijų darbininkų privilegijos kitų kategorijų darbininkų atžvilgiu.

9-as paragrafas numate i̇monių darbininkų tarybų, apskričių darbininkų tarybos ir krašto darbininkų tarybos sudarymą tam, „kad užtikrinus darbininkams galimybes aktyviai dalyvauti darbo ir uždarbio sąlygų nustatyme, lygiai kaip ir krašto gamybos jègų vystyme“.

10-u paragrafu siekta Konstitucijoje įtvirtinti būtinumą sudaryti apskričių ūkio tarybas bei krašto ūkio tarybą. Šios tarybos, socialdemokratų požiūriu, buvo reikalingos „eliminuoti aklą ekonominių jègų veikimą“ ir pakeisti ją „kolektyvine kontrole nustatyti planingą krašto ūkio vystymąsi“. I minètas ūkio tarybas turejo įeiti „atstovai nuo darbininkų tarybų, pramonès organizacijų, kooperatyvų ir užinteresuotų liaudies sluoksnių (konsumentų)“. Ūkio tarybos turi būti sudarytos taip, „kad jose būtų atstovaujamos darbo šakos sulig jų svarbumo ūkio ir socialiniu žvilgsniu“.

11-as socialdemokratų Konstitucijos priedo paragrafas numatè tai, kad visi ịstatymų projektai, „kurie turi pamatines reikšmės ūkio ir socialiniais žvilgsniais“, prieš

134 Socialdemokratų frakcijos pasiūlytasai priedas ị konstituciją. Socialdemokratas. 192202 06, Nr. 6, p. 2. 
„innešant juos ị Seimą“ "turi būti vyriausybès pateikti aptarti krašto ūkio tarybai, kurios nuomonę apie ịstatymą vyriausybè turi pateikti Seimui kartu su įstatymo projektu. 12-ame paragrafe buvo numatyta Krašto ūkio tarybos teisè teikti vyriausybei įstatymų „sumanymus, kurie liečia tą arba kitą ūkio arba socialinio gyvenimo sritį“. Vyriausybe net ir nepritardama „tiems sumanymams turèjo pateikti juos Seimui išdèsčius savo nusistatymą". 13-ame paragrafe buvo numatyta, jog Valstybès ūkio taryba turèjo turèti „teisès ginti savo ịstatymų sumanymus Seime per savo atstovą". 14-as paragrafas numate darbininkų ir ūkio taryboms kontrolès teisę tose darbo ir ūkio srityse, kurios bus pavestos joms įstatymais.

15-u paragrafu buvo „istatymo keliu visam kraštui ir visose darbo srityse“ nustatomas 48 darbo valandų per savaitę maksimumas. 16-as paragrafas ịtvirtino nuostatą, kad „už tą patị darbą vyrai ir moterys gauna tą patị atlyginimą". 17-as paragrafas panaikino naktinị darbą, išskyrus tas ịstaigas ir ịmones, kur to reikalauja „technikinès sąlygos arba darbo rūšis". Taip pat čia buvo numatyta, kad atlyginimai už naktinị darbą mokami „aukštesnèmis normomis negu už dienos darbąa“.

18-as LSDP frakcijos parengto Konstitucijos projekto priedo paragrafas nustaté, kad néščiosios moterys „paliuosuojamos nuo darbo“ dešimčiai savaičiu - keturias prieš gimdymą ir šešias po gimdymo. Per tą laiką jos turi gauti atlyginimą „ligoninių kasų normomis“.

19-as paragrafas uždraudé vaikų iki 15 metų darbą pramonès įmonėse, o 20-as paragrafas nustate, jog nuo 15 iki 18 metų abiejų lyčiu vaikai gali dirbti pramonès imonèse, bet ne daugiau kaip 6 valandas per dieną su privaloma 1,5 valandos pertrauka. Dirbantiems vaikams turi būti suteikta galimybè bent 2 valandas per dieną lankyti techninio ir bendro lavinimo klases, specialiai dẻl jų įsteigtas prie pramonés įstaigu arba prie tam tikrų mokyklų.

21-u paragrafu buvo pasisakoma už tai, kad „valstybè privalo taip sutvarkyti ir aprūpinti lèšomis bendro technikinio lavinimo mokyklas, lygai kaip ir aukštąsias mokyklas, kad visos tos švietimo ịstaigos būtų prieinamos darbininkų klasei“".

Peržvelgę socialdemokratų nuolatinès Konstitucijos priedą „Ükio skyrius“, matyt, galime teigti, jog čia išdėstytų nuostatų prièmimas būtų leidęs Lietuvoje igyvendinti ar bent jau konstituciškai fiksuoti tam tikro laipsnio socialinę ir ekonominę demokratiją arba bent jau tam tikras prielaidas jai igyvendinti.

Nors šis socialdemokratų teiktas nuolatinès Konstitucijos projekto priedas ir buvo svarstomas St. Seimo Konstitucijos komisijoje, tačiau priimta ir paredaguotose versijose liko tik keletas (socialinès ir darbo apsaugos srityse) iš šiame priede teiktų pataisų, kurios atsispindejo Konstitucijos „Valstybes ekonominès politikos pagrindų“ bei „Socialès apsaugos“ skyriuose fiksuotose nuostatose ${ }^{135}$. Socialdemokratai buvo labai nepatenkinti tuo, kad jų priede „Ūkio skyrius“ teiktos nuostatos iš Konstitucijos projekto „taip sakant, kaip ir pranyko“ ir kad dèl to „gavosi kaip ir pasityčiojimas“"136.

135 Iš St. Seimo komisijų, supra note 73, p. 3.

136 Steigiamojo Seimo darbai. 218 p-dis, p. 95. 
1922 m. vasarą prasidejjus trečiajam Lietuvos Respublikos Konstitucijos projekto svarstymui, socialdemokratų frakcijos pateiktų Konstitucijos projekto 18-os pataisų pakete, be jau anksčiau minètų, keletas pataisų buvo skirta tam tikrų socialinès ir ekonominès politikos nuostatų fiksavimui Konstitucijoje ${ }^{137}$. Pavyzdžiui, viena šių pataisų buvo siekiama savivaldos ūkio sritims įtvirtinimo, buvo pasisakoma už tai, kad „istatymo keliu turi būti ịsteigti darbo, žemès ūkio, pramonès ir kitokie rūmai, sujungti i vienus visam kraštui rūmus“. Čia pat dèl to, kad „ūkio gyvenimas reikalinga tvarkyti“ ir „visos gamintojų pajègos turi būti organizuotos“, buvo pasisakyta ir už tai, kad „ūkio organizacijos turi turèti tinkamo balso ir prie įstatymų leidimo“.

Socialdemokratai taip pat siekè ịtvirtinti pagrindiniame Lietuvos įstatyme nuostatą, jog „Valstybė ir savivaldybė dalyvauja privatinių ūkių ir ūkio sąjungų valdyme“, „kai kuriais atvejais gali jas suvisuomeninti“. Socialdemokratų nuomone, tokios ūkio įmonès, kurios bus reikalingos visuomenès reikalams, gali būti savivaldybių ir valstybės paimtos ir „ūkis jose pertvarkytas taip, kad iš to būtų visuomenei naudos“. Socialdemokratų nuomone, ši pataisa Konstitucijai buvo „labai svarbus siūlymas“.

LSDP frakcija taip pat siekè Konstitucijoje ịtvirtinti nuostatą, jog „žemé, savininko neišdirbta, nusavinama, lygiai kaip ir žemé, reikalinga namų statymui dẻl butų stokos arba žemès ūkio pakèlimui“. Socialdemokratai tokią Konstitucijos pataisą motyvavo tuo, kad „stambūs ūkininkai, dvarininkai tyčia apleidžia žemes ir paverčia jas dirvonais“, tad tokias žemes „reikia nusavinti ir duoti tiems, kas nori ją dirbti“.

Konstitucijoje socialdemokratai siekè ịtvirtinti ir nuostatą, jog „žemès kainos padidejjimas, kuris neišeina iš darbo arba kapitalo ị ją ịdejjimo, nusavinimas visuomenès reikalams“. Pasak LSDP frakcijos narių, „žemès, gulinčios arti miestų, prie patogių susisiekimo punktų ir t. t., ir be didelio darbo ir kapitalo įdejjimo duoda gražių pelnų jos savininkams (vadinama žemès renta)“. Taigi, buvo pasisakoma „už tų pelnų iš žemių, kurie atsiranda ne iš įdèto žemèje darbo ir kapitalo, nusavinimą visuomenès reikalams ir jos naudai“.

Viena iš savo Konstitucijos projekto pataisų socialdemokratai ir toliau siekè, kad pagrindiniame šalies ịstatyme būtų fiksuota nuostata, jog tam, kad darbininkai galètų aktyviai „dalyvauti uždarbio ir darbo sąlygų nustatyme, lygiai ir krašto gamybos jègų vystyme“, turi būti „sudaromos ịmonių darbininkų tarybos ir viso krašto darbininkų taryba“. Tai buvo apibūdinta kaip „svarbiausias darbininkų reikalavimas“. Socialdemokratai reikalavo, kad kiekvienoje įmoneje, kur tik dirba darbininkai, būtų sudarytos darbininkų tarybos (bei darbininkų komitetai), kurios turètų kontrolès teises darbo ir ūkio srityse. To meto socialdemokratų nuomone, ūkio gyvenimo ir uždarbio klausimuose darbininkai turèjo turèti „sprendžiamojo balso“ teisę, per savo atstovus privalèjo turèti teises dalyvauti Ūkio rūmuose, spręsti krašto ūkio reikalus, teikti savo pasiūlymus ir t. t. Beje, tokią teisę turejjo turèti ne tik įmonių tarybos, bet ir

137 Žr., pavyzdžiui, 13-16 bei 17-18, o iš dalies ir 15 pataisas. Žr. Socialdemokratų frakcijos pataisos teikiamos III Lietuvos Konstitucijos svarstymui, supra note 87, p. 1. Visų kitų tekste čia toliau pateikiamų socialinio ekonominio pobūdžio pataisų pristatymas paremtas šioje nuorodoje nurodytu dokumentu. 
visos darbininkų organizacijos - profsąjungos "gaminimo ir vartotojų kooperacijos“. Darbininkų tarybų sudarymas ir jų sudarymo teisès įtvirtinimas Konstitucijoje buvo, socialdemokratų įsitikinimu, „be galo svarbus dalykas“.

Gindami „darbo demokratiją“, socialdemokratai siekė Konstitucijoje ịtvirtinti „savaime suprantamą" nuostatą apie „koalicijų, organizacijų ir streikų laisvę visiems fizinio ir proto darbo žmonėms“. Nepavykus pasiekti, kad būtų priimtos jų priede „Ükio skyrius" pateiktos konstitucinès nuostatos, ịtvirtinančios socialinès bei ekonominès demokratijos (pagal to meto socialdemokratų sampratą) tam tikrus aspektus, socialdemokratai mégino dar kartą šias nuostatas ịtraukti ị Konstituciją, pateikdami minètą pataisų paketą trečiajam projekto skaitymui.

Šias pataisas išspausdinusiame „Socialdemokrate“ (1922 07 20) buvo rašoma, kad nepaisant to, „bus ar nebus tos pataisos priimtos (turima mintyje ne tik socialinés ekonominés problematikos pataisos, bet ir anksčiau minètos pataisos - G. M.), darbininkų klasei jos yra labai svarbios, todèl tolimesne kova už tas teises turès eiti ir ateity“, todèl ir LSDP organizacijos, ir „visi sąmoningi darbininkai privalo tas socialdemokratų frakcijos pataisas aptarti ir gerai jas įsidemèti“, nes ko negali atlikti LSDP frakcija, „privalès atlikti visa Lietuvos darbininkija“138.

„Socialdemokrate“ buvo rašoma, jog socialdemokratų frakcija pateikè savo pataisas tam, kad Konstitucijoje būtų ginami darbininkų reikalai, „tuo tarpu kai didžiuma (St. Seimo dauguma - G. M.) leidžiamąja Konstitucija nori sudaryti tvirtą pamatą buržuazijai, kurią krikščionys atstovauja būsimai kovai su darbininkais“. Iš cituojamo straipsnio, kuriame buvo griežtai kritiškai vertinama tai, jog Seimo dauguma nepriemè didelès dalies socialdemokratų siūlomų pataisų, buvo matyti ir tai, kad socialdemokratai netikejjo, jog bus priimtos ir likusios jų teikiamos Konstitucijos pataisos. Čia buvo rašoma, jog „nežiūrint visų socialdemokratų frakcijos pastangų, nèra jokios vilties, kad praeitu" " jos pateiktos Konstitucijos projekto pataisos, nes St. Seime trečią kartą svarstant Konstitucijos projektą „pilnoj šviesoj paaiškejjo krikščionių demokratų ir jų pridurkų „federacininkų“ veidas“.

Iš tiesų St. Seimo dauguma neprièmé socialinio ekonominio pobūdžio nuostatas turinčiu įtvirtinti Konstitucijos pataisų. Dèl to, socialdemokratų vertinimu, „Seimo dauguma išbraukë“ iš jų „,pasiūlymo viską, kas užstotų darbininkų reikalams, išbraukè net sąjungų ir streiko teisę darbininkams ir tarnaujantiems ir paliko tik tai, kas gina privačią nuosavybę, darbdavị prieš samdininką, turtingą prieš beturtị “139.

\section{Socialdemokratų frakcija priimant nuolatinę Konstituciją 1922 m. rugpjūčio $1 \mathrm{~d}$.}

Kaip mateme iš ankstesnių šio straipsnio skyrelių, absoliuti dauguma socialdemokratų Konstitucijos projekto pasiūlymų bei pataisų buvo St. Seimo daugumos

138 Krikščionys ir konstitucija. Socialdemokratas. 192207 20, Nr. 29, p. 1.

139 Steigiamojo Seimo darbai. 234 p-dis, 192208 01, p. 47; Socialdemokratų frakcijos deklaracija dèl konstitucijos įstatymo, supra note 92, p. 1. 
atmesta. Tiesa, buvo ir tokių socialdemokratų Konstitucijos projekto siūlymų, kuriuos St. Seimo dauguma prièmė, pavyzdžiui: siūlymas Lietuvos Konstituciją vadinti ne Lietuvos Valstybės, bet Lietuvos Respublikos Konstitucija ${ }^{140}$; siūlymas palikti proporcinę rinkimų sistemą, iš dešinès pusès kilus pasiūlymui jos atsisakyti ${ }^{141}$; siūlymas ị Konstituciją įrašyti nuostatą, kad iniciatyvą ją keisti, be Seimo, turètų 50 tūkst. Lietuvos piliečių, o ne „dešimta dalis Lietuvos piliečių“, kaip kad siūlè krikščionys demokratai ir kas, anot V. Čepinskio, būtų apie 100 tūkst. Lietuvos piliečių ${ }^{142}$.

Tačiau šie ir dar kai kurie kiti priimti socialdemokratų Konstitucijos projekto siūlymai sudarè tik labai mažą dalị itin aktyviai Konstitucijos prièmimo procese dalyvavusių socialdemokratų pasiūlymų ir pataisų ir nekeite jų aiškiai neigiamo priimtos Konstitucijos vertinimo, kurị mėginta išdèstyti jų frakcijos atstovų pareiškime-deklaracijoje 1922 m. rugpjūčio 1 d., kai vyko galutinis balsavimas už visą Konstituciją (ir jos prièmimas). Visas pareiškimas paskelbtas rugpjūčio $3 \mathrm{~d}$. „Socialdemokrate“143.

Minètą dieną pagaliau po daugelị posėdžių trukusių ilgų ir karštų ịvairių politinių jègų debatų dèl nuolatinès Lietuvos Respublikos Konstitucijos socialdemokratai iš pradžių savo pareiškime kritiškai apibūdinę krikščionių demokratų bloko daugumą St. Seime bei atkreipę demesi i tai, kad jie nuo darbo St. Seime pradžios žinojo, kokiomis sąlygomis jiems teks dirbti ir „ko galès atsiekti“ savo kovoje „gindami darbininkų reikalus ir demokratijos pamatinius siekimus“, toliau trumpai apibūdino minètos kovos aplinkybes bei ypatybes.

Socialdemokratai savo deklaracijoje dèl Konstitucijos prièmimo konstatavo, kad jiems vesti minètą kovą St. Seimo darbo pradžioje sąlygos tam tikra prasme buvo šiek tiek palankesnès, nes tuo metu „tiek visoj Europoj, tiek ir pas mus“ reiškęsis „proletarinès revoliucijos gyvas alsavimas buvo tiek galingas, kad ji jautė labiausiai įdiržėjęs reakcininkas“, tad ir Lietuvos krikščionys demokratai turèjo atsižvelgti ị šią revoliucinę laikmečio atmosferą.

Tuo tarpu „St. Seimo darbus baigiant“, pasak socialdemokratų, padetis pakito, nes „reakcija pakèlè galvą visoj Europoj ir net trigubai sustiprejo ir pas mus“, todèl baigdamas svarstyti Konstitucijos ịstatymą „krikščionių blokas nebemato reikalo bent kuo varžytis“. Pasak LSDP frakcijos, kova dèl Konstitucijos buvo „ilga ir atkakli“ ir jos metu „pasireiškè visi pamatiniai skirtumai“ tarp skirtingų politinių jègų, visų pirma „tarp mūsų (tai yra socialdemokratų - G. M.) ir klerikalų“, kurie „toje kovoje, kad ir nenorom turejo išsirèdyti ir parodyti tikrąji savo veidą“ ir „kurie kovos kely Seime neteko visų pripuolamų sèbrų ir pasiliko vieni patys" (turima mintyje tai, kad 1922 m. pradžioje koaliciją su krikščionių demokratų bloku nutraukẻ valstiečių liaudininkų blokas).

140 Iš St. Seimo. Socialdemokratas. 192203 16, Nr. 11, p. 22.

141 Steigiamojo Seimo darbai.184 p-dis, 192203 17, p. 44-45.

142 Steigiamojo Seimo darbai. 218 p-dis, 192206 28, p. 94.

143 Steigiamojo Seimo darbai. 234 p-dis, 192208 01, p. 46-48; Socialdemokratų frakcijos deklaracija dèl konstitucijos įstatymo, supra note 92, p. 1-2. 
Toliau socialdemokratų deklaracijoje buvo apibūdinta tai, „dèl ko jie kovėsi“ Konstitucijos priemimo procese - trumpai išvardintos svarbiausios nuostatos, kurių ịrašymo ị Konstituciją siekè socialdemokratai, bei pateikti vertinimai, kodẻl jos (kiekviena atskirai) nepateko ị Konstituciją. Kadangi visos šios nuostatos ir jų vertinimai jau pateikti šiame straipsnyje, nesikartodami pereikime prie socialdemokratų deklaracijos pabaigoje pateikto bendresnio $1922 \mathrm{~m}$. rugpjūčio $1 \mathrm{~d}$. priimtos (deklaracijos skaitymo metu dar tik priimamos) Konstitucijos įvertinimo.

LSDP frakcijos deklaracijoje buvo sakoma, kad St. Seimo dauguma, atmesdama svarbiausias socialdemokratų siūlytas Konstitucijos projekto pataisas, ,išreiške savo reakcinị veidą“ bei „sudarkè, susiaurino ir net paniekè turinị visos eilès kitų konstitucijos paragrafų, paniekdama pačios konstitucijos vertę". Čia taip pat buvo pažymèta, jog „beveik visos“ LSDP frakcijos „dètos didžiausios pastangos apginti darbo demokratijos reikalus Konstitucijos įstatyme liko bergždžios“. Tačiau nepaisant to, LSDP frakcija pareiškè, kad „būsimojo gyvenimo kūrẻjas ir Lietuvoje yra darbo demokratija“, kad „ir Lietuvoje darbininkų klasei yra lemta eiti besivystančios ateities priešaky, eiti prie to tikslo, kurị yra sau pastatęs socialistinis pasaulio proletariatas" ir kad „to kelio darbininkų klasei negali pastoti jokios rašytosios konstitucijos, nei jų dabartiniai rašèjai“.

Pažymédami, kad „kova už geresnę ateitị bus tuo sunkesnè, kuo reakcija daugiau kliūčių tai kovai statys" ir kad St. Seimo dauguma, atmetusi LSDP frakcijos Konstitucijos pataisas, taip ir daro ir dèl to minètoji kova „bus aštresnè ir skaudesné“ nei „kaip galètų būti žmoniškai tvarkomoje visuomenejje“, už ką „moraliai atsakinga yra „aklai užsispyrusi, klasiniai - egoistinè (St. Seimo - G. M.) dauguma“, socialdemokratų frakcijos nariai pabrèžè, kad jie „padarẻ viską, ką jiems liepė pareiga“ "galutinio konstitucijos balsavimo valandoje“ ir „neima jokios atsakomybès už taip sudarytąji pamatinị krašto įstatymą" ir kad galutiniame jo balsavime jie nedalyvaus ${ }^{144}$.

Taip ir įvyko 1922 m. rugpjūčio 1 d. Kadangi balsavime, be socialdemokratų, nedalyvavo ir taip pat kritiškai, tik, žinoma, ne taip radikaliai galutinị Konstitucijos tekstą vertinę valstiečių liaudininkų bloko nariai, tai $1922 \mathrm{~m}$. Konstitucija buvo priimta 59-ių St. Seimo atstovų balsais.

Rekonstravę ir aptarę Lietuvos socialdemokratų nuostatas Lietuvos Respublikos 1920 m. birželio 2 d. laikinosios Konstitucijos bei 1922 m. rugpjūčio 1 d. nuolatinès Konstitucijos prièmimo procese galime teigti, kad to meto socialdemokratų konstitucinès nuostatos buvo suponuotos ne tik „laikmečio dvasios“, kilusios iš nedemokratinių monarchijų griūties po 1917-1918 m. revoliucijų bei po Pirmojo pasaulinio karo pasireiškusio demokratinio entuziazmo ir radikalaus parlamentarizmo (prancūziškosios jo versijos) idejų - visa tai veikè (tik skirtingu laipsniu) ir kitas pagrindines St. Seime atstovaujamas Lietuvos politines partijas, - bei veikiamos Šveicarijos konstitucinès- politinès tradicijos ${ }^{145}$. To meto Lietuvos socialdemokratu

144 Supra note 143.

145 Žr. apie tai: Rèmeris, M., supra note 3, p. 122-135. 
konstitucinès nuostatos buvo nulemtos ir jų vadovavimosi viena iš to meto radikalesnių socialistinių marksistinès socializmo doktrinos interpretacijų ${ }^{146}$, jų bendrųjų ideologinių-politinių nuostatų bei politinės laikysenos įvairiais politinio ir socialinio visuomenès gyvenimo klausimais ${ }^{147}$, Lietuvos socialdemokratijos ideologinès-politinès tradicijos ${ }^{148}$, socializmo ideologinès tradicijos apskritai ${ }^{149}$ bei buvo veikiamos to meto europininio socialistinio judejimo raidos ypatybių ${ }^{150}$, to meto LSDP veiklos aplinkybių ir ypatybių ${ }^{151}$, politinių debatų St. Seime ypatybių ${ }^{152}$ ir to meto Lietuvos politinès kultūros apskritai ${ }^{153}$.

\section{Išvados}

Ištyrus ir rekonstravus socialdemokratų dalyvavimą Lietuvos Respublikos $1922 \mathrm{~m}$. rugpjūčio 1 d. nuolatinès Lietuvos Respublikos Konstitucijos prièmimo procese bei jų gintas konstitucines nuostatas, apibendrinant galima teigti, jog tiek priimant $1920 \mathrm{~m}$. laikinąją Lietuvos Respublikos Konstituciją, tiek ir 1922 m. rugpjūčio 1 d. nuolatinę Lietuvos Respublikos Konstituciją, to meto socialdemokratai sieké Lietuvoje įtvirtinti kiek galima radikaliau parlamentinę demokratinę valdymo formą, o per ją ne tik radikalią politinę, bet ir socialinę bei ekonominę demokratiją. Ypač nesutaikomai priešiški to meto Lietuvos socialdemokratai buvo, jų nuomone, dẻl demokratijai prieštaraujančios prezidento institucijos.

Straipsnyje aptariamo laikotarpio Lietuvos socialdemokratų konstitucinės nuostatos buvo veikiamos "laikmečio dvasios“, kilusios iš nedemokratinių monarchijų griūties po1917-1918 m. revoliucijų, bei po Pirmojo pasaulinio karo pasireiškusio „demokratinio entuziazmo“, radikaliai parlamentinès „prancūziškos“ demokratijos

146 Žr. Mitrulevičius, G. Kas yra socialdemokratu partija: Stepono Kairio ir jo vadovaujamos tarpukario LSDP atsakymai [interaktyvus]. [žiūrèta 2013-01-03]. <www.lsds.lt>.

147 Ibid; Mitrulevičius, G. Socialdemokratai Lietuvos Respublikos seimuose 1920-1927, supra note 5.

148 Žr. Mitrulevičius G. Socialdemokratų vaidmuo Lietuvos valstybingumo (at)kūrimo idejjos atgimimo procese (XIX a. pabaiga - 1918 m.). Gairés. 2008, 2: 35-44.

149 Žr. Sassoon, D. One Hundread of Socialism. The West European Left in the Twentieth Century. New York: I. B. Tauris, 1996; Shubin, A. Socializm. "Zolotoj vek” teorii [Socialism." Golden age" of theory]. Moskva: Novoe literaturnoe obozrenie, 2007; Karlson, I.; Lindgren, A. M. Kas yra socialdemokratija. Vilnius: Gairès, 2002.

150 Žr. Braunthal, J. Geschichte der Internacionale. Band 2. Berlin, Bonn: Verlag J.H.W. Dietz Nachf.GmbH, 1978.

151 Mitrulevičius, G. Socialdemokratų (LSDP) santykis su Lietuvos Respublikos demokratizacijos procesu, supra note 5, p. 79-124.

152 Kasperavičius, A. Steigiamasis Seimas ir jo oratoriai. Lietuvos istorijos studijos. 2003, 12: 36-46.

153 Kasparavičius, A. Parlamentarizmo ir politinès kultūros problemos Lietuvoje 1920-1926 metais. Parlamento studijos. 6, 2006, p. 43-70; Kasparavičius, A. Achilo kulnas: parlamentarizmo ir politinès kultūros problemos Lietuvoje 1920-1926 metais. Kultūros barai. 2007, Nr. 1, p. 65-70; Nr. 2, p. 70-74; Nr. 3, p 69-75; Nr. 4, p. 62-65. 
versijos išpopuliarejjimo, taip pat Šveicarijos politinès tradicijos ịtakos. To meto Lietuvos socialdemokratų konstitucinèms nuostatoms ịtaką darè ir vadovavimasis viena iš to meto radikalesnių socialistinių marksistinès socializmo doktrinos interpretacijų bei socializmo ideologine tradicija apskritai, to meto europinio socialistinio judejjimo raidos ypatybès, ir, žinoma, to meto LSDP veiklos aplinkybès ir ypatybès.

Visa tai ir lèmé, kad to meto socialdemokratų pateikiamas tiek prezidento institucijos pagal 1922 m. Lietuvos Respublikos Konstituciją vertinimas, tiek ir šios Konstitucijos vertinimas apskritai ne vienu atveju buvo hipertrofuotas ir nepakankamai adekvatus žvelgiant ị visa tai iš šių dienų pozicijų.

\section{Literatūra}

Bielinis, K. Gana to jungo. New York: K. Bielinio ir Amerikos liet. Socialdemokratų s-gos lit. fondas, 1971.

Blažytė, D. Socialdemokratų frakcija Steigiamajame Seime. Socialine demokratija Lietuvoje: LSDP ištakos ir raida. Vilnius: Vilniaus universiteto leidykla, 1996.

Blažytė-Baužienè, D.; Tamošaitis, M.; Truska, L. Lietuvos Seimo istorija XXXXI a. pradžioje. Vilnius: Baltos lankos, 2009.

Braunthal, J. Geschichte der Internacionale. Band 2. Berlin, Bonn: Verlag J.H.W. Dietz Nachf.GmbH, 1978.

Čepenas, P. Naujuju laiku Lietuvos istorija. T. 2. Chicago: Dr. Kazio Griniaus fondas, 1986.

Daugirdaitè-Sruogienè, V. Lietuvos Steigiamasis Seimas. New York: Lithuanian National Fuondation Inc Tautos fondas, 1975.

Ilgūnas, G. Steponas Kairys. Vilnius: Vaga, 2002.

Jakštas, J. Nepriklausomos Lietuvos istorija. Chicago, 1992.

Karlson, I.; Lindgren, A. M. Kas yra socialdemokratija. Vilnius: Gairès, 2002.

Kasparavičius, A. Achilo kulnas: parlamentarizmo ir politinès kultūros prob- lemos Lietuvoje 1920-1926 metais. Kultūros barai. 2007, 1, 2, 3, 4.

Kasparavičius, A. Parlamentarizmo ir politinès kultūros problemos Lietuvoje 1920-1926 metais. Parlamento studijos. 2006, 6 .

Kasperavičius, A. Steigiamasis Seimas ir jo oratoriai. Lietuvos istorijos studijos. 2003, 12.

Kašauskienė, V. Socialdemokratų opozicija LKDP konstitucinèms nuostatoms Steigiamajame Seime. Lietuvos Respublikos Konstitucija penkeriu metu perspektyvoje. Konferencijos medžiaga. Vilnius: LII leidykla,1998.

Lietuvos Konstitucijos projekto rengiamosios komisijos byla. LCVA. F. 923. Ap. 1. B. 122.

Lietuvos Respublikos konstituciné teise. Vilnius: Lietuvos teisès universitetas, 2001.

Lietuvos teisès istorija. Vilnius: Justitia, 2002.

Lietuvos Valstybès Laikinosios Konstitucijos pamatiniai dèsniai. Lietuvos valstybès konstitucijos. Vilnius: Mokslas, 1989.

Mačionis, Z.; Čepinskis, J. Profesorius Vincas Čepinskis. Vilnius: Mokslas, 1992. 
Maksimaitis, M. Lietuvos teisès šaltiniai 1918-1940 metais. Vilnius: Justitia, 2001.

Maksimaitis, M. Lietuvos valstybès konstituciju istorija. Vilnius: Justitia, 2005.

Maksimaitis, M. Mažoji Konstituanta. Lietuvos Taryba atkuriant valstybinguma. Vilnius: Justitia, 2011.

Maksimaitis, M. Parlamentarizmo teisinis reguliavimas Lietuvoje 1918-1940 metais. Parlamentas ir valstybinès valdžios instituciju sqranga. Liber Amicorum Česlovui Juršénui. Vilnius: Mykolo Romerio universitetas, 2008.

Maksimaitis, M.; Vansevičius, S. Lietuvos valstybès ir teisés istorija. Vilnius: Justitia, 1997.

Mitrulevičius, G. Kas yra socialdemokratu partija: Stepono Kairio ir jo vadovaujamos tarpukario LSDP atsakymai [interaktyvus]. [žiūrèta 2013-01-03]. <www. lsds.lt>.

Mitrulevičius, G. Socialdemokratų vaidmuo Lietuvos valstybingumo (at)kūrimo idejos atgimimo procese (XIX a. pabaiga - 1918 m.). Gairés, 2008, 2.

Mitrulevičius, G. Socialdemokratai 1922 metų Lietuvos Respublikos Konstitucijos priemimo procese (1920-1922 m.). Gairès. 2007, 7, 8.

Mitrulevičius, G. Socialdemokratai Lietuvos Respublikos seimuose 1920-1927. Socialdemokratai Lietuvos Respublikos seimuose. Vilnius: Petro ofsetas, 2006.

Mitrulevičius, G. Socialdemokratų (LSDP) santykis su Lietuvos Respublikos demokratizacijos procesu Steigiamojo Seimo darbo metu 1920-1922 m. Parlamento studijos. 2010, 9.

Mitrulevičius, G. Socialdemokratų santykis su Lietuvos (Valstybès) Taryba $1918 \mathrm{~m}$.: nuo Vasario 16-osios Akto prièmimo iki Pirmojo pasaulinio karo pabaigos. Parlamento studijos. 2013, 14.

Mūsu konstitucionalizmo raida. Vilnius: Seimo l-kla „Valstybès žinios“, 2003.

Noreikienè, S. Buržuazinès partijos seimų rinkimuose buržuazinio parlamentinio režimo Lietuvoje metais (1920-1926). 1. Steigiamojo Seimo rinkimai. Lietuvos TSR mokslu akademijos darbai, A serija. 1978, 1(62). Prezidentas valstybinès valdžios instituciju sistemoje. Vilnius: Leidykla MES, 2011.

Račkauskas, K. Lietuvos konstitucinès teisés klausimai. New York: s.n.,1967.

Rèmeris, M. Lietuvos konstitucinès teisès paskaitos. Vilnius: Mintis, 1990.

Rüsen, J. Istorika. Vilnius: Margi raštai, 2007.

Sassoon, D. One Hundread of Socialism. The West European Left in the Twentieth Century. New York: I. B. Tauris, 1996.

Shubin, A. Socializm. „Zolotoj vek“ teorii [Socialism."Golden age" of theory]. Moskva: Novoe literaturnoe obozrenie, 2007.

Socialdemokratas. 1920-1922.

Steigiamojo Seimo darbai. Kaunas, 19201922.

Švoba, J. Seimine ir prezidentine Lietuva. Vilnius: Vyturys, 1990.

Truska, L. Steigiamasis Seimas ir jo vieta naujųjų laikų Lietuvos istorijoje. Lietuvos Steigiamojo Seimo (1920-1922 metu) narių biogragfinis žodynas. Vilnius: Vilniaus pedagoginio universiteto leidykla, 2006.

Vilčinskas, J. Lietuvos socialdemokratija kovoje dèl krašto nepriklausomybès. Istorinè apžvalga. London: Nida Press, 1985. 


\title{
VISION OF RADICALLY DEMOCRATIC REPUBLIC: PROVISIONS OF THE SOCIAL-DEMOCRATIC FACTION OF THE CONSTITUENT SEIMAS IN THE PROCESS OF RECEPTION OF THE CONSTITUTION (1922)
}

\author{
Gintaras Mitrulevičius \\ Mykolas Romeris University, Lithuania
}

Summary. The aim of the article is to research, reconstruct, present and discuss the provisions of faction of social-democrats of the Constituent Seimas and LSDP in general in the process of reception of the temporary Constitution (June 2, 1920) and the permanent Constitution (August 1, 1922) of the Republic of Lithuania. Summarizing, it can be stated that social-democrats of that period aimed to consolidate radical parliamentary democratic form of governance, which had to consolidate not only radical political democracy, but social and economic democracy, as well. Social-democrats of that period were implacably hostile to the institution of the president, which they considered not democratic.

It should be stated that constitutional provisions of social-democrats were caused by the spirit of the times originated from the collapse of undemocratic monarchies during the revolutions in 1917 and 1918, popularity of democracy in its radically parliamentary, 'french' version, adherence to one of the most radical socialistic interpretations of marxistic doctrine and ideological tradition of socialism in general. Also, they were exposed by circumstances and characteristics of LSDP activities at that time. All of that resulted into hypertrophied and not adequate assessment of presidential institutions according to the permanent Lithuanian Constitution of the Republic of Lithuania (1922) and assessment of this Constitution in general.

Keywords: Constituent Seimas, Constitution of the Republic of Lithuania (1922), faction of Social-democrats, LSDP.

Gintaras Mitrulevičius, Mykolo Romerio universiteto Politikos ir vadybos fakulteto Politikos mokslų instituto lektorius. Mokslinių tyrimų kryptys: socialdemokratija, komunizmas, politinè kairé, politinès ideologijos.

Gintaras Mitrulevičius, Mykolas Romeris University, Faculty of Politics and Management, Department of Political Sciences, lecturer. Research interests: Social Democracy, communism, political left, political ideologies. 